\title{
GLASS FABRICATION AND PRODUCT CONSISTENCY TESTING OF LANTHANIDE BOROSILICATE FRIT X COMPOSITION FOR PLUTONIUM DISPOSITION
}

James C. Marra

Charles L. Crawford

Ned E. Bibler

November 2006

Savannah River National Laboratory

Aiken, SC 29808

Prepared for the U.S. Department of Energy Under Contract Number DEAC09-96SR18500

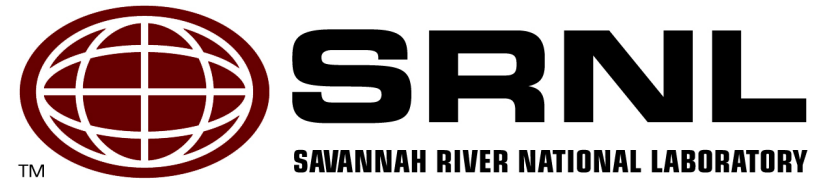




\section{DISCLAIMER}

This report was prepared by Washington Savannah River Company (WSRC) for the United States Department of Energy under Contract No. DE-AC09-96SR18500 and is an account of work performed under that contract. Neither the United States Department of Energy, nor WSRC, nor any of their employees makes any warranty, expressed or implied, or assumes any legal liability or responsibility for the accuracy, completeness, or usefulness, of any information, apparatus, or product or process disclosed herein or represents that its use will not infringe privately owned rights. Reference herein to any specific commercial product, process, or service by trademark, name, manufacturer or otherwise does not necessarily constitute or imply endorsement, recommendation, or favoring of same by WSRC or by the United States Government or any agency thereof. The views and opinions of the authors expressed herein do not necessarily state or reflect those of the United States Government or any agency thereof.

Printed in the United States of America

Prepared For

U.S. Department of Energy 
Key Words: Plutonium disposition, Plutonium glass durability, Leach testing

Retention: Permanent

\section{GLASS FABRICATION AND PRODUCT CONSISTENCY TESTING OF LANTHANIDE BOROSILICATE FRIT X COMPOSITION FOR PLUTONIUM DISPOSITION}

James C. Marra

Charles L. Crawford

Ned E. Bibler

November 2006 
WSRC-STI-2006-00318

Revision 0

\section{REVIEWS AND APPROVALS}

\section{AUTHOR(S):}

James C. Marra, Materials Science and Technology

Date

Charles L. Crawford, Process Science and Engineering

Date

Ned E. Bibler, Process Science and Engineering

Date

\section{TECHNICAL REVIEWER:}

David Peeler, Process Science and Engineering

Date

\section{APPROVERS}

Natraj C. Iyer, Director, Materials Science and Technology

Date

Richard E. Edwards, Manager, Process Science and Engineering

Date

David P. Eisele, Nuclear Materials Management Engineering

Date 


\section{EXECUTIVE SUMMARY}

The Department of Energy Office of Environmental Management (DOE/EM) plans to conduct the Plutonium Disposition Project at the Savannah River Site (SRS) to disposition excess weapons-usable plutonium. A plutonium glass waste form is the preferred option for immobilization of the plutonium for subsequent disposition in a geologic repository. A reference glass composition (Lanthanide Borosilicate (LaBS) Frit B) was developed during the Plutonium Immobilization Program (PIP) to immobilize plutonium in the late 1990's. A limited amount of performance testing was performed on this baseline composition before efforts to further pursue $\mathrm{Pu}$ disposition via a glass waste form ceased. Recent FY05 studies have further investigated the LaBS Frit B formulation as well as development of a newer LaBS formulation denoted as LaBS Frit X. The objectives of this present task were to fabricate plutonium loaded LaBS Frit X glass and perform corrosion testing to provide near-term data that will increase confidence that LaBS glass product is suitable for disposal in the Yucca Mountain Repository. Specifically, testing was conducted in an effort to provide data to Yucca Mountain Project (YMP) personnel for use in performance assessment calculations.

Plutonium containing LaBS glass with the Frit X composition with a $9.5 \mathrm{wt} \% \mathrm{PuO}_{2}$ loading was prepared for testing. Glass was prepared to support Product Consistency Testing (PCT) at Savannah River National Laboratory (SRNL). The glass was thoroughly characterized using x-ray diffraction (XRD) and scanning electron microscopy coupled with energy dispersive spectroscopy (SEM/EDS) prior to performance testing. A series of PCTs were conducted at SRNL using quenched Pu Frit $\mathrm{X}$ glass with varying exposed surface areas. Effects of isothermal and can-in-canister heat treatments on the Pu Frit X glass were also investigated. Another series of PCTs were performed on these different heat-treated $\mathrm{Pu}$ Frit $\mathrm{X}$ glasses. Leachates from all these PCTs were analyzed to determine the dissolved concentrations of key elements. Acid stripping of leach vessels was performed to determine the concentration of the glass constituents that may have sorbed on the vessels during leach testing. Additionally, the leachate solutions were ultrafiltered to quantify colloid formation.

Characterization of the quenched $\mathrm{Pu}$ Frit $\mathrm{X}$ glass prior to testing revealed that some crystalline plutonium oxide was present in the glass. The crystalline particles had a disklike morphology and likely formed via coarsening of particles in areas compositionally enriched in plutonium. Similar results had also been observed in previous Pu Frit B studies. Isothermal $1250^{\circ} \mathrm{C}$ heat-treated $\mathrm{Pu}$ Frit $\mathrm{X}$ glasses showed two different crystalline phases $\left(\mathrm{PuO}_{2}\right.$ and $\left.\mathrm{Nd}_{2} \mathrm{Hf}_{2} \mathrm{O}_{7}\right)$, as well as a peak shift in the XRD spectra that is likely due to a solid solution phase $\mathrm{PuO}_{2}-\mathrm{HfO}_{2}$ formation. Micrographs of this glass showed a clustering of some of the crystalline phases. Pu Frit X glass subjected to the can-in-canister heating profile also displayed the two $\mathrm{PuO}_{2}$ and $\mathrm{Nd}_{2} \mathrm{Hf}_{2} \mathrm{O}_{7}$ phases from XRD analysis. Additional micrographs indicate crystalline phases in this glass were of varying forms (a spherical $\mathrm{PuO}_{2}$ phase that appeared to range in size from submicron to 5 micron, a dendritic-type phase that was comprised of mixed lanthanides and plutonium, and a minor phase that contained $\mathrm{Pu}$ and $\mathrm{Hf}$ ), and clustering of the phases was also observed. 
A series of PCTs were conducted at $90^{\circ} \mathrm{C}$ in ASTM Type- 1 water. The Product Consistency Test - Method A (PCT-A) was conducted to compare the Pu LaBS Frit X glass durability to current requirements for High Level Waste (HLW) glass in a geologic repository. The PCT-A test has a strict protocol and is designed to specifically be used to evaluate whether the chemical durability and elemental release characteristics of a nuclear waste glass have been consistently controlled during production and, thus, meet the repository acceptance requirements. The PCT-A results on the Pu containing LaBS Frit X glass showed that both the quenched and heat-treated glasses are very durable. Comparison of the PCT data for Pu Frit X glass (quenched or heat-treated) vs. the Environmental Assessment (EA) glass data shows that the average normalized release for the Pu Frit X glass is $>300$ times lower based on B and $>30$ times lower based on $\mathrm{Si}$. The PCT-B normalized elemental release rates for the quenched Pu Frit X glass, which involved higher surface area to volume ratios, were similar to the normalized elemental release values from PCT-A testing. This further indicated that the LaBS Frit X glass is very durable as measured by the PCT.

All of the PCT leachates in this study were first filtered through prototypical $0.45 \mu \mathrm{m}$ syringe filters. In addition, all of the Pu glass leachates were further filtered through micro filters to assess whether colloids formed during the leaching. Comparison of the initial syringe-filtered leachates to the ultrafiltered leachates indicated that normalized plutonium releases were essentially the same for the quenched $\mathrm{Pu}$ Frit $\mathrm{X}$ glasses.

Ultrafiltered leachates showed $\sim 30 \%$ lower Pu than filtered leachates for both of the heat-treated $\mathrm{Pu}$ Frit X glasses, suggesting presence of possible colloidal plutonium species in the heat-treated glass leachates.

Several items were identified in this testing where further analysis and testing are needed. Microstructure characterization of the $\mathrm{Pu}$ Frit X glass shows evidence of a $\mathrm{PuO}_{2}-\mathrm{HfO}_{2}$ solid solution phase. However, quantitative determination of the relative amounts of $\mathrm{Pu}$ and $\mathrm{Hf}$ in this phase is not possible unless standard solid solution $\mathrm{PuO}_{2}-\mathrm{HfO}_{2}$ phases can be made and characterized. $\mathrm{PuO}_{2}-\mathrm{HfO}_{2}$ samples should be produced and characterized to support this effort.

PCT-B testing should be conducted for longer (up to one year) durations on the Frit B composition and the present Frit X composition (both quenched and heat-treated) to provide additional insight into colloid and alteration phase formation. Archived samples of $\mathrm{Pu}$ Frit B and Pu Frit X glass have been made in the present study to support these long term tests. Long term static PCTs could be conducted in an oven located inside of a radiochemical hood to allow for better monitoring and vessel tightening by hand vs. previous 28-day and 56-day PCTs performed remotely in the Shielded Cells Facility (SCF). 
Analytical methods for dissolution and characterization of the Pu LaBS glasses have been examined in this work. Surrogate frit dissolutions have been performed and the resulting dissolved frit solutions have been analyzed by non-radioactive sample instrument analyses using ICP-AES capable of analyzing for all eight of the frit elemental components. These data were then compared to separate analyses using radioactive sample instrument analyses (ICP-AES and ICP-MS) that would be used for analyses of actual $\mathrm{Pu}$-bearing glasses. Initial results from this comparison indicate sufficient agreement between the methods (ICP-AES non-rad vs. combined ICP-AES and ICP-MS for radioactive solutions). Thus these preliminary glass characterization analyses should be extended to actual Pu-bearing glasses to confirm the glass composition. 
TABLE OF CONTENTS

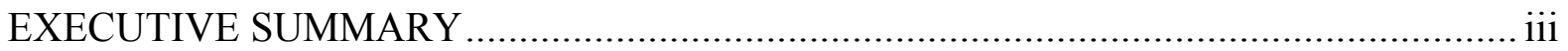

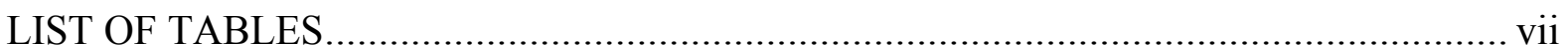

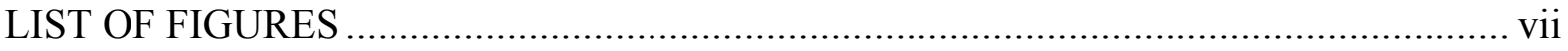

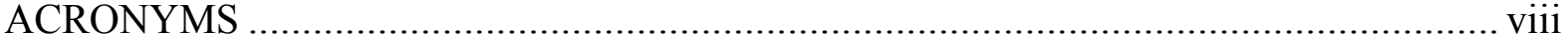

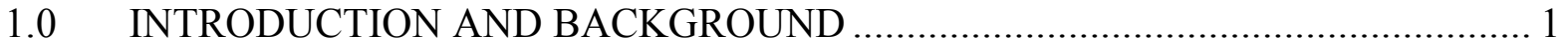

$1.1 \quad$ Recent Pu LaBS Glass Work .................................................................. 1

1.2 Current Pu LaBS Frit X Studies............................................................... 2

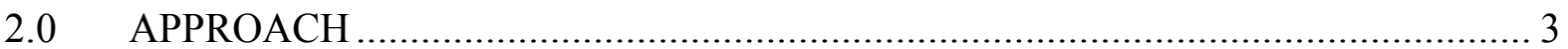

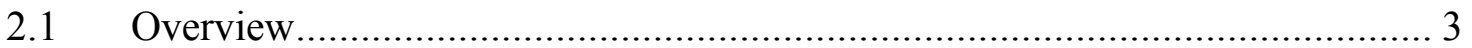

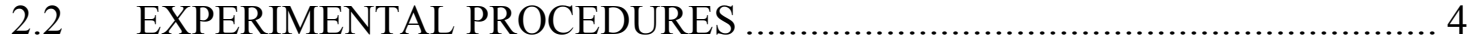

2.2.1 Plutonium Glass Fabrication .............................................................. 4

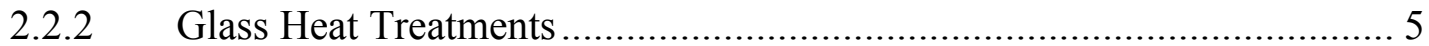

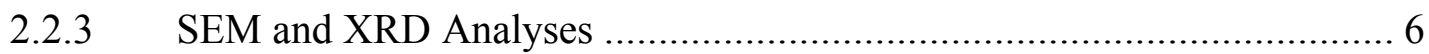

2.2.4 Product Consistency Test (PCT) ……………................................. 6

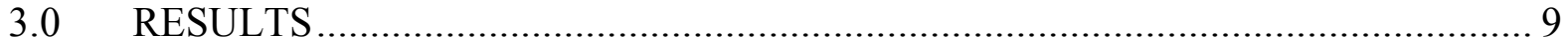

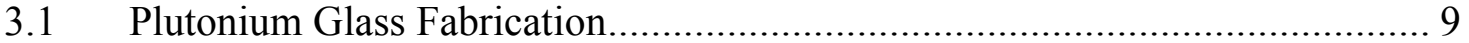

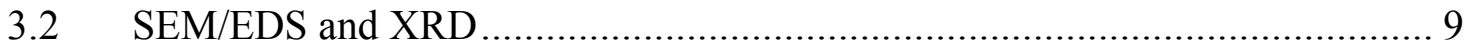

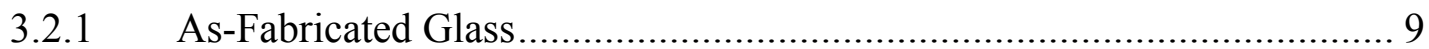

3.2.2 Isothermal Heat-Treated Glasses........................................................ 12

3.2.3 Can-in-Canister Thermal Profile Heat-Treated Glasses ........................... 15

3.3 Results of the PCT-A and PCT-B on As-Fabricated (Quenched) Glass .......... 18

3.4 Results of the PCT-A on Heat-Treated Pu Frit X Glass.................................. 26

3.5 Comparison of Filtration vs. Ultrafiltration Data............................................ 32

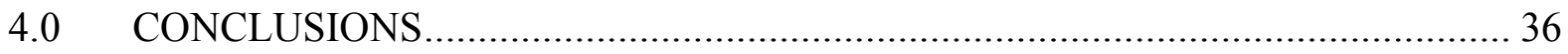

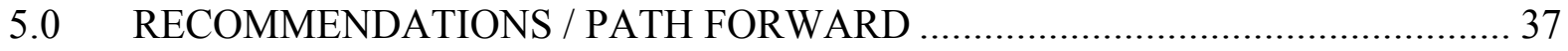

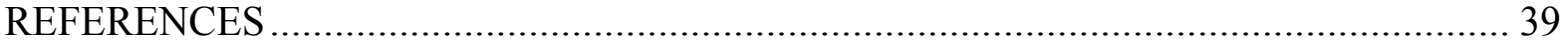




\section{LIST OF TABLES}

Table 2-1. LaBS Glass Compositions used in Previous (Frit A and Frit B) Testing and

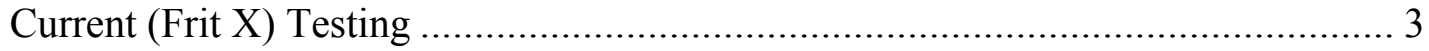

Table 2-2. Method Detection Limits for ICP-AES and ICP-MS ............................. 8

Table 3-1. Pu Frit X Analysis............................................................................ 9

Table 3-2. Summary of PCTs Performed on Quenched Pu Frit X Glass .................... 22

Table 3-3. Concentration and $\mathrm{pH}$ Data for the Filtered Leachates from Quenched Pu Frit

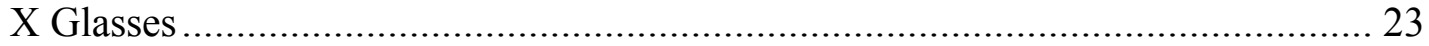

Table 3-4. Concentration Data for the Acid Strip Solutions from Quenched Pu Frit X

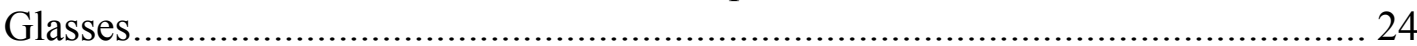

Table 3-5. Normalized Release Values for Pu Frit X Quenched Glasses and EA Glass 25

Table 3-6. Summary of PCTs Performed on Heat-Treated Pu Frit X Glass................. 28

Table 3-7. Concentration and $\mathrm{pH}$ Data for the Filtered Leachates from Heat-Treated Pu

Frit X Glasses ................................................................................................ 29

Table 3-8. Concentration Data for the Acid Strip Solutions from Heat-Treated Pu Frit X

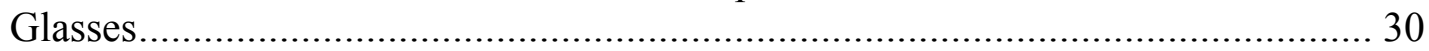

Table 3-9. Normalized Release Values for Pu Frit X Quenched Glasses and EA Glass 31

Table 3-10. Concentrations from Ultrafiltered (UF) and Filtered (Filt.) Leachates....... 33

\section{LIST OF FIGURES}

Figure 3-1. XRD scan of plutonium Frit $\mathrm{X}$ glass showing undissolved $\mathrm{PuO}_{2} \ldots \ldots \ldots \ldots 10$ Figure 3-2. SEM micrograph and corresponding EDS spectra showing undissolved crystalline $\mathrm{PuO}_{2}$ in the as-fabricated Frit X glass....................................... 11

Figure 3-3. XRD scan of plutonium Frit X glass thermally treated at $1250^{\circ} \mathrm{C}$. The apparent peak shift could be indicative of the presence of a $\mathrm{PuO}_{2}-\mathrm{HfO}_{2}$ solid solution phase.

Figure 3-4. SEM micrograph and corresponding EDS spectra showing the presence of a proposed $\mathrm{PuO}_{2}-\mathrm{HfO}_{2}$ solid solution phase in the glass................................ 13

Figure 3-5. SEM micrograph and corresponding EDS spectra showing the presence of a proposed $\mathrm{PuO}_{2}-\mathrm{HfO}_{2}$ solid solution phase in the bulk heat-treated glass. .............. 14

Figure 3-6. XRD Scan of Canister Thermal Profile Indicating Presence of Crystalline $\mathrm{PuO}_{2}$ and $\mathrm{Nd}_{2} \mathrm{Hf}_{2} \mathrm{O}_{7}$ in the Glass

Figure 3-7. SEM micrograph and corresponding EDS spectra showing the presence of multiple crystalline phases in the canister thermal treatment glass. ...................... 16

Figure 3-8. Pu Concentrations from Filtered and Ultrafiltered Leachates.................... 34 Figure 3-9. La Concentrations from Filtered and Ultrafiltered Leachates.................... 34 Figure 3-10. Nd Concentrations from Filtered and Ultrafiltered Leachates .................. 35

Figure 3-11. Gd Concentrations from Filtered and Ultrafiltered Leachates ................. 35 


\section{ACRONYMS}

\begin{tabular}{|c|c|}
\hline ATS & Actinide Technology Section \\
\hline ASTM & American Society for Testing and Materials \\
\hline ARM-1 & Approved Reference Material - 1 \\
\hline ANL & Argonne National Laboratory \\
\hline $\mathrm{DOE} / \mathrm{EM}$ & Department of Energy Office of Environmental Management \\
\hline SRS & Savannah River Site \\
\hline LaBS & Lanthanide Borosilicate \\
\hline PIP & Plutonium Immobilization Program \\
\hline YMP & Yucca Mountain Project \\
\hline PCT & Product Consistency Testing \\
\hline SRNL & Savannah River National Laboratory \\
\hline XRD & $\mathrm{x}$-ray diffraction \\
\hline $\mathrm{SEM} / \mathrm{EDS}$ & $\begin{array}{l}\text { scanning electron microscopy coupled with energy dispersive } \\
\text { spectroscopy }\end{array}$ \\
\hline HLW & High Level Waste \\
\hline DWPF & Defense Waste Processing Facility \\
\hline SPFT & Single Pass Flow Through \\
\hline WAPS & Waste Acceptance Product Specifications Document \\
\hline EA & Environmental Assessment \\
\hline TGA & Thermal Gravimetric Analysis \\
\hline SCF & Shielded Cells Facility \\
\hline $\mathrm{SA} / \mathrm{V}$ & surface area to volume \\
\hline NMWL & nominal molecular weight limit \\
\hline ICP-AES & Inductively Coupled Plasma - Atomic Emission Spectroscopy \\
\hline ICP-MS & Inductively Coupled Plasma - Mass Spectroscopy \\
\hline EQL & estimated quantification limits \\
\hline PQL & practical quantification limits \\
\hline MES & multielement standards \\
\hline $\mathrm{ppb}$ & part-per-billion \\
\hline PNNL & Pacific Northwest National Laboratory \\
\hline PSAL & Process Science Analytical Laboratory \\
\hline
\end{tabular}




\subsection{INTRODUCTION AND BACKGROUND}

The Department of Energy Office of Environmental Management (DOE/EM) plans to conduct the Plutonium Disposition Project at the Savannah River Site (SRS) to disposition excess weapons-usable plutonium. Vitrification appears to be the preferred option for the disposition of the plutonium. A reference LaBS glass composition was developed during the Plutonium Immobilization Program (PIP) to immobilize plutonium in the late 1990's (Myers, 1998). An important part of the vitrification approach is to reduce the attractiveness of the plutonium by fabricating a plutonium glass form and immobilizing the Pu form within the high level waste (HLW) glass prepared in the Defense Waste Processing Facility (DWPF). This requires that the Pu Disposition Project schedule is consistent with EM plans for immobilizing HLW in the DWPF. Therefore, several inputs are needed to provide confidence that the Pu Disposition Project will meet the project schedule. Key inputs are near-term data that will increase confidence that the LaBS glass product is suitable for disposal in the Yucca Mountain Repository.

\subsection{Recent Pu LaBS Glass Work}

A workshop was held on April 28, 2005 at the Bechtel SAIC Company facility in Las Vegas, NV to define the near-term data needs. Dissolution rate data and the fate of plutonium oxide and the neutron absorbers during the dissolution process were defined as key data needs. A suite of short-term tests were defined at the workshop to obtain the needed data. The objectives of these short-term tests are to obtain data that can be used to show that the dissolution rate of a LaBS glass is acceptable and to demonstrate that the extent of $\mathrm{Pu}$ separation from neutron absorbers, as the glass degrades and dissolves, is not likely to lead to criticality concerns. Previous FY05 testing at SRNL addressed initial short-term 7-day corrosion testing and some 28-day and 56-day corrosion tests with crucible studies using a Pu Frit B formulation (Marra, 2006a). A related study involving monolithic $\mathrm{Pu}$ Frit $\mathrm{B}$ corrosion testing and vapor hydration testing on Pu Frit B composition (Ebert, 2006) has also been reported from Argonne National Laboratory (ANL). An additional data need was identified regarding the degree of macroscopic cracking that occurs during processing of the $\mathrm{Pu}$ glass waste form and subsequent pouring of HLW glass in the DWPF. Earlier SRNL work also investigated macroscopic cracking from melter runs using surrogate Hf Frit B compositions (Jones, 2006). A final need to evaluate new frit formulations that may increase the durability of the plutonium glass and/or decrease the degree to which neutron absorbers separate from the plutonium during dissolution was also identified. Alternative LaBS frit formulations were investigated and limited heat treatment studies were conducted on surrogates and a single $\mathrm{Pu}$ LaBS glass using a Frit X composition (Marra, 2006b). 


\subsection{Current Pu LaBS Frit X Studies}

This report covers FY06 testing to support the near-term data needs regarding glass dissolution performance using the Pu Frit $\mathrm{X}$ composition. The effects of heat treatment on Pu Frit X glass structure (as measured by XRD and SEM/EDS) and durability (as defined by the PCT) are also investigated. A related Pacific Northwest National Laboratory (PNNL) study involving preliminary results for Single Pass Flow Through (SPFT) corrosion tests on surrogate $\mathrm{Hf}$ Frit $\mathrm{X}$ and $\mathrm{Pu}$-containing Pu Frit $\mathrm{X}$ glasses (Pierce, 2006) has been recently reported.

The PCT was identified as a means to provide some of the near-term performance data. The PCT is a static test method in which known masses of crushed glass and ASTM Type-1 purified water are reacted for a desired duration (PCT, 2002). The PCT Method A test is conducted under specific test conditions: $90^{\circ} \mathrm{C} ; 7$ days; $-100+200$ mesh-size glass; water/glass mass ratio of 10:1. The PCT Method B allows for varying the test conditions (temperature, duration, and glass/water mass ratio are commonly varied). Under PCT conditions, components that are released from the glass as it dissolves accumulate in the solution throughout the test and affect the degradation rate through solution feedback effects. The primary feedback effects are through the effects of dissolved silica and increased $\mathrm{pH}$. The extent of degradation under these tests conditions can be compared with that of other waste forms.

Results from the PCT are used as a measure of acceptance in the Waste Acceptance Product Specifications Document (WAPS) (WAPS, 1996). WAPS provides the repository acceptance requirements for vitrified HLW glass. A current acceptance criterion for HLW glass is that the PCT Method A response must be less than the response of the Environmental Assessment (EA) benchmark glass, after normalizing the glass compositions. The average rate in the PCT Method A test, based on the amount of boron released over 7 days, is used as one measure to determine the maximum rate, or $\mathrm{k}_{\mathrm{E}}$ value, that is used in the HLW glass degradation model in alkaline solutions (Ebert, 2006 and BSC, 2004). Immersion tests as a function of both $\mathrm{pH}$ and temperature are also used to determine maximum dissolution rates (Ebert, 2006). Longer term PCT static tests using both the previous Frit B composition and the current Frit X composition are also planned to provide data to verify the applicability of the degradation model. No long term PCTs were performed in this work. However, adequate amounts of the Pu Frit B quenched glass and the Pu Frit X quenched glasses have been vitrified in this work and previous studies, and are currently in archive storage in SRNL for these tests. 


\subsection{APPROACH}

\subsection{Overview}

Previous performance testing on LaBS glass was predominantly performed on the Frit A and Frit B compositions (Marra 2006a and references cited therein). The objectives of this task were to prepare $\mathrm{Pu}$ loaded LaBS glass with a $9.5 \mathrm{wt} \% \mathrm{PuO}_{2}$ loading using the current reference Frit X composition for testing, perform PCTs under varying conditions, and analyze the leachates from the PCTs. Plutonium containing LaBS glass with the Frit X composition (Table 2.1) was prepared at the SRNL for testing. A series of 7-day PCTs were conducted at $90^{\circ} \mathrm{C}$ in stainless steel vessels with varying exposed surface area. The leachates from these tests were analyzed to determine the dissolved concentrations of key elements. Additionally, the leachate solutions were ultrafiltered to quantify colloid formation. The PCT vessels were also acid stripped and the strip solution analyzed to more accurately quantify the dissolved element concentrations.

Table 2-1. LaBS Glass Compositions used in Previous (Frit A and Frit B) Testing and Current (Frit X) Testing

\begin{tabular}{|c|c|c|c|}
\hline & FRIT A & FRIT B & FRIT X \\
\hline OXIDE & MASS \% & MASS \% & MASS \% \\
\hline $\mathrm{Al}_{2} \mathrm{O}_{3}$ & 21.5 & 21.3 & 10.0 \\
\hline $\mathrm{B}_{2} \mathrm{O}_{3}$ & 11.7 & 11.6 & 13.0 \\
\hline $\mathrm{Gd}_{2} \mathrm{O}_{3}$ & 8.6 & 12.8 & 13.5 \\
\hline $\mathrm{HfO}_{2}$ & -- & 6.6 & 7.0 \\
\hline $\mathrm{La}_{2} \mathrm{O}_{3}$ & 12.4 & 8.1 & 19.0 \\
\hline $\mathrm{Nd}_{2} \mathrm{O}_{3}$ & 12.8 & 8.2 & 15.0 \\
\hline $\mathrm{SiO}_{2}$ & 29.2 & 28.9 & 20.0 \\
\hline $\mathrm{SrO}_{2 \mathrm{O} O}$ & 2.5 & 2.5 & 2.5 \\
\hline $\mathrm{ZrO}_{2}$ & 1.3 & -- & - \\
\hline
\end{tabular}




\subsection{EXPERIMENTAL PROCEDURES}

\subsubsection{Plutonium Glass Fabrication}

To facilitate fabrication of the plutonium glass, frit was first prepared in a non-radioactive environment. The frit was prepared by mixing reagent grade chemicals in the proportion for the Frit X glass composition. Oxide chemicals were used for all components except for boron. Boric acid was used to provide the necessary $\mathrm{B}_{2} \mathrm{O}_{3}$ content in the frit. The frit batch was melted at $1500^{\circ} \mathrm{C}$ in $\mathrm{Pt} / \mathrm{Rh}$ crucibles. After nominally two hours at temperature, the crucible was removed from the furnace at temperature and the molten glass poured on a steel plate. The "cullet" pieces were collected for subsequent grinding. The cullet was ground in an automated agate milled and sieved to collect the fraction that was -325 mesh $(<45 \mu \mathrm{m})$. An aliquot of the powdered frit material was dissolved by peroxide fusion and analyzed by ICP-ES to check the composition.

The Actinide Technology Section (ATS) of SRNL prepared the plutonium oxide used in this experiment. The original source of the plutonium was SRS F-area B-Line sweepings, which were not well characterized other than they were primarily weaponsgrade material. The sweepings were dissolved in a nitric acid solution with a small amount of potassium fluoride added. The solution was then purified by processing through an anion exchange column. Due to the amount of product expected and the size of the anion exchange column, two separate purification runs were required. After purification, each batch was processed individually.

The first processed batch was used for all $\mathrm{Pu}$ LaBS glass fabrication presented in this study. The second batch is archived for future work. The first batch ion exchange column product was treated with oxalic acid to precipitate plutonium oxalate. The oxalate was then calcined to plutonium oxide. The first batch was initially calcined for three hours at $450^{\circ} \mathrm{C}$. Inspection of the calcined mass of this material suggested further calcining was necessary so the first batch was again calcined an additional three hours at $500^{\circ} \mathrm{C}$. The second batch ion exchange column product was also treated with oxalic acid to precipitate plutonium oxalate. The second batch was calcined at $800^{\circ} \mathrm{C}$ for three hours. Both calcined batches weighed about $10 \%$ more than expected from the alpha and gamma analysis of the starting material. A sample from the first batch was run through a Thermal Gravimetric Analysis (TGA) and was found to contain about $3 \mathrm{wt} \%$ water. This first batch of $\mathrm{PuO}_{2}$ was used in this study and the small amount of measured moisture in the $\mathrm{PuO}_{2}$ was accounted for in the batching of Pu Frit $\mathrm{X}$ glass. The second batch of $\mathrm{PuO}_{2}$ remains for further $\mathrm{Pu}$ vitrification studies. 
The frit was weighed into the appropriate amount to produce glass with a target $\mathrm{PuO}_{2}$ loading of $9.5 \mathrm{wt} \%$. The frit was placed in a plastic bottle for introduction into the SRNL Shielded Cells Facility (SCF). In the Shielded Cells, the appropriate quantity of $\mathrm{PuO}_{2}$ was weighed and added to the bottle containing the frit. The mass of $\mathrm{PuO}_{2}$ was adjusted for the small $\sim 3 \mathrm{wt} \%$ of moisture content detected in the $\mathrm{PuO}_{2}$. The bottle was capped and the mixture manually mixed for a few minutes using the rotation afforded by the manipulator arm. The mixture of frit and $\mathrm{PuO}_{2}$ was placed in a $\mathrm{Pt} / \mathrm{Rh}$ crucible for melting.

The open, uncovered $\mathrm{Pt} / \mathrm{Rh}$ crucible was placed in a high temperature $\mathrm{CM}$ Furnace, Inc., elevator furnace and the furnace was ramped to the nominal melting temperature of $1500^{\circ} \mathrm{C}$ using a ramp rate of $10^{\circ} \mathrm{C} /$ minute. The melt was held at temperature for approximately 4 hours, removed from the furnace, and immediately quenched in a pan of water. Upon cooling, the glass was manually removed from the crucible by "hammering" the crucible. In this manner nominally $99 \%$ of the original glass monolith was recovered from the crucible as various sized pieces. In an effort to enhance homogenization of the glass, the glass pieces were collected into a second $\mathrm{Pt} / \mathrm{Rh}$ crucible and melted a second time using the same methodology used for the initial melt.

\subsubsection{Glass Heat Treatments}

Previous testing indicated that it may be possible to intentionally crystallize a $\mathrm{PuO}_{2}-\mathrm{HfO}_{2}$ solid solution phase in the glass (Marra, 2006b). To further investigate this potential, heat treatment studies were conducted on the Frit X composition glass containing plutonium. Based on previous crystallization testing with surrogate LaBS Frit X composition glasses ( $\mathrm{Hf}$ as a surrogate for $\mathrm{Pu}$ ) and limited testing with $\mathrm{Pu}$ Frit $\mathrm{X}$ glass, isothermal hold temperatures of $1250-1300^{\circ} \mathrm{C}$ were of specific interest (Marra, 2006b). Initially, small samples of glass were heat-treated to identify experimental conditions that precipitated the desired crystalline phase. The small samples $(\sim 1 \mathrm{~g})$ were placed in a $\mathrm{Pt} / \mathrm{Rh}$ crucible and heat-treated according to the prescribed thermal conditions. The heat treatment protocol using the programmed CM Furnace involved: heating to $1500^{\circ} \mathrm{C}$ over an $\sim 2$-hour interval, followed by a step to the desired isothermal temperature of $1250^{\circ} \mathrm{C}$ with the temperature reduction from $1500^{\circ} \mathrm{C}$ to $1250^{\circ} \mathrm{C}$ occurring in less than fifteen minutes, and holding at $1250^{\circ} \mathrm{C}$ for 4 hours, and quenching to room temperature by removing the crucible from the furnace and placing in water. These small samples were analyzed by SEM/EDS and XRD to assess crystallization and formation of other potential heterogeneities within the glass. The XRD and SEM/EDS results from this initial small sample test indeed showed formation of Pu-containing phases in addition to the minor crystalline $\mathrm{PuO}_{2}$ phase present in the as-fabricated glass (see Section 3.2 below for discussion). Thus a larger portion of glass (approximately $25 \mathrm{~g}$ ) was subjected to the thermal treatment in a similar manner. The resulting glass was also analyzed by SEM/EDS and XRD. The leach performance of the heat-treated glass was also evaluated using the PCT.

\footnotetext{
${ }^{1}$ Previous testing (Vienna, 1996) demonstrated that co-grinding the $\mathrm{PuO}_{2}$ and the frit and manual stirring of the melt enhanced $\mathrm{PuO}_{2}$ dissolution in the melt. These techniques could not be used in the current fabrication facility.
} 
To facilitate disposition of the Pu glass form in a geologic repository, the can-in-canister technology will be used. In the can-in-canister technology, the cans of Pu glass will be placed in a HLW glass canister and subsequently filled with high level waste glass to surround the cans of plutonium glass with highly radioactive waste glass. During the HLW glass pouring process, the cans of Pu glass will be subjected to elevated temperatures. The can-in-canister pouring process was demonstrated in 2000 using fullscale HLW canisters (Smith, et al., 2000). In one phase of this testing, a canister was instrumented with thermocouples to determine thermal conditions during the pour process. The "worst-case" (maximum temperature of $900^{\circ} \mathrm{C}$ ) thermal data at the surface of a can from the prototype can-in-canister testing was utilized for heat treating the Frit $\mathrm{X}$ composition $\mathrm{Pu}$ glass. The heat treatment protocol involved: heating to $900^{\circ} \mathrm{C}$ and holding for 0.5 hour, followed by a 21 -hour controlled cooling down to $240^{\circ} \mathrm{C}$. This heat-treated glass was also characterized by SEM/EDS and XRD and evaluated using the PCT.

\subsubsection{SEM and XRD Analyses}

XRD and SEM/EDS were used to analyze both the as-fabricated and heat-treated glasses. Specifically, the analyses were used to examine for the presence of crystalline species by powdered-sample XRD and other heterogeneities observed from the SEM micrographs and corresponding EDS that may be in the glass. The crystalline species could result from undissolved matter in the glass or phases that crystallized from the glass. The latter was of specific interest for the glasses subjected to the $1250^{\circ} \mathrm{C}$ isothermal heat treatment and glass subjected to the can-in-canister thermal profile. Analyses were conducted on < $1 \mathrm{~g}$ glass shard samples that were broken from larger as-melted or heat-treated glass pieces. The samples were mounted on an aluminum stub using double-sided tape to facilitate analysis in the SEM. Crushed glass powdered samples were mounted on glass slides using collodion and amyl acetate, followed by drying, and then analyzed by XRD.

\subsubsection{Product Consistency Test (PCT)}

The PCT is an American Society for Testing and Materials (ASTM) Standard Test (ASTM 1285 - 02) for leaching nuclear waste forms. With regard to glass it is a crushed glass static leach test performed in sealed vessels at $90^{\circ} \mathrm{C}$ using ASTM Type- 1 water. The ASTM Type-1 water was prepared using a Barnstead Nanopure Infinity ${ }^{\mathrm{TM}}$ ultrapure water system capable of filtering the water to at least $18 \mathrm{Mohmcm}$. Two types of PCTs were used to evaluate the durability of the Pu LaBS glass prepared with Frit X. One was the PCT-A test and the other, PCT-B.

The PCT-A test has a strict protocol and was designed to specifically be used to evaluate whether the chemical durability and elemental release characteristics of a nuclear waste glass have been consistently controlled during production. The test, which is performed in stainless steel vessels with $10.0 \pm 0.5 \mathrm{~mL}$ of ASTM water per gram of glass for a 7-day duration, includes appropriate blanks and standards (EA glass and the Approved Reference Material - 1 (ARM-1) glass) as prescribed by the ASTM procedure. 
The PCT-B allows the researcher more flexibility in the leach test parameters such as varied surface area to volume $(\mathrm{SA} / \mathrm{V})$ ratios, varied leach vessel material (steel vs. Teflon), and varied leachant matrices, leach times and temperatures. The PCT-A test and the PCT-B test with higher SA/V ratios were applied to triplicate samples of the Pu LaBS Frit X quenched glass. The PCT-A test was also applied to triplicate samples of the $\mathrm{Pu}$ LaBS Frit X glass that had been both isothermally heat-treated and can-in-canister cooled.

Upon completion of the 7-day PCT, all leachates were carefully decanted into clean specimen vials remotely in the SCF. These vials were then transferred to a radiochemical hood where a small aliquot of the leachate was $\mathrm{pH}$ tested. The $\mathrm{pH}$ of the leachates was measured using an Accumet $\mathrm{pH}$ meter/probe along with certified buffer solutions. The PCT leachates were then filtered using $45 \mu \mathrm{m}$ filter. Nalgene ${ }^{\circledR} 0.45 \mu \mathrm{m}$ syringe filters (25-mm surfactant free cellulose acetate membrane) fitted with 20-mL latex-free Luer$\mathrm{LOK}^{\mathrm{TM}}$ syringes in the PCT-A. Filtered leachates were diluted and acidified with ultrapure concentrated nitric acid before analyses.

All of the Pu Frit X leachates were additionally filtered through micro filters to assess whether colloids formed during the leaching a $90^{\circ} \mathrm{C}$. This filtering referred to as 'ultrafiltration' used high-flow Biomax-PB polyether sulfone membrane filters that are 30,000 nominal molecular weight limit (NMWL). These filters are listed as 'UltrafreeCL Centrifugal Filter Units' from Millipore Corp. This ultrafiltration requires a centrifuge to force the leachate through the filter.

Ultrafiltration of the $\mathrm{Pu}$ glass leachates for this study used the Millipore ultrafilters described above in a Thermo IEC Centra CL2 centrifuge unit that was fit with a \#221 rotor. This rotor is a 6-place fixed trunniun swinging bucket design with nominal 3500 RPM maximum speed capability. The ultrafilters were pre-wetted with ASTM Type-1 water. Pre-wetting involved adding $\sim 2 \mathrm{~g}$ of ASTM Type- 1 water to the filter and centrifuging for 5 minutes on the maximum RPM setting. This typically pre-wetted the filter with $<0.03 \mathrm{~g}$ of water. The pre-wetted ultrafilters were then used to filter the previously $0.45 \mu \mathrm{m}$ filtered Pu Frit X PCT leachates. Ultrafiltered leachates were diluted and acidified with ultrapure concentrated nitric acid before analyses.

Two different analytical methods were used in order to analyze for all of the glass components in all of the $0.45 \mu \mathrm{m}$ filtered leachates. Using Inductively Coupled Plasma Atomic Emission Spectroscopy (ICP-AES) the Pu Frit X glass leachates were analyzed for Al, B, Si, and Sr. ICP-AES was also used to analyze for $\mathrm{Na}$ and $\mathrm{Li}$ in the EA and ARM-1 glass leachates. Using Inductively Coupled Plasma - Mass Spectroscopy (ICP$\mathrm{MS}$ ) the Pu Frit X glass leachates were analyzed for $\mathrm{Pu}, \mathrm{La}, \mathrm{Nd}, \mathrm{Gd}$, and Hf. The ultrafiltered leachates were only analyzed by ICP-MS. The elemental method detection limits for these instruments as they were applied to the radioactive leachate solutions are given in Table 2.2 in units of $\mu \mathrm{g} / \mathrm{L}$ or part-per-billion (ppb). These values are determined for both the ICP-AES and the ICP-MS by multiplying the standard deviation from measuring multiple undiluted blank solutions by 10X. Thus the values shown in Table 2.2 are analogous with estimated quantification limits (EQLs) or practical quantification limits (PQLs). The ICP-AES data is typically reported with a $10 \%$ uncertainty in analyses and the ICP-MS data is typically reported with a $20 \%$ uncertainty in analyses. 
Table 2-2. Method Detection Limits for ICP-AES and ICP-MS

\begin{tabular}{|c|c|c|}
\hline Method & Element & Method Detection Limit \\
\hline & & $(\mu \mathrm{g} / \mathrm{L})$ \\
\hline ICP-AES & $\mathrm{Al}$ & 22 \\
\hline & $\mathrm{B}$ & 92 \\
\hline & $\mathrm{Si}$ & 732 \\
\hline & $\mathrm{Sr}$ & 43 \\
\hline & $\mathrm{Li}$ & 48 \\
\hline & $\mathrm{Na}$ & 185 \\
\hline $\mathrm{ICP}-\mathrm{MS}$ & $\mathrm{La}$ & 0.08 \\
\hline & $\mathrm{Nd}$ & 0.02 \\
\hline & $\mathrm{Gd}$ & 0.02 \\
\hline & $\mathrm{Hf}$ & 0.025 \\
\hline & $\mathrm{Pu}$ & 0.01 \\
\hline
\end{tabular}

The Pu Frit X glass PCT vessels were acid-stripped after the PCT. This involved removal of the leached powdered glass from the steel vessels via remote handling in the SRNL SCF. After removal of the leachate from the PCT vessels, the damp, powdered leached glasses were dried in the PCT oven overnight at $90^{\circ} \mathrm{C}$. The dried glass was then poured/removed into a container for archive storage. This removed all the visible glass from the PCT vessels. The empty PCT vessels were then rinsed three successive times with ASTM Type-1 water. The rinse water was collected and the empty PCT vessels were examined using an ocular eyepiece through the cell window to verify that all visible glass was removed. After these steps, the PCT vessels were again dried overnight at $90^{\circ} \mathrm{C}$, removed from the SCF and transferred to a radiochemical hood for an additional triple rinse with ASTM Type-1 water. A volume of $18 \mathrm{~mL}$ ASTM Type-1 water and 6 drops of concentrated ultrapure nitric acid was added to the vessels that were then heated at $90^{\circ} \mathrm{C}$ for 24 hours inside of a drying oven located in a radiochemical hood. Each strip solution was then directly analyzed (without dilution) by both ICP-AES and ICP-MS. 


\subsection{RESULTS}

\subsection{Plutonium Glass Fabrication}

Table 3-1 shows analyzed values of Pu Frit X starting frit vs. the targeted values. These data from peroxide fusion dissolution and ICP-AES analyses indicate that the frit was within $+/-5 \%$ of target on an oxide basis.

Table 3-1. Pu Frit $X$ Analysis

\begin{tabular}{|l|l|l|l|l|l|l|l|l|l|l|}
\hline Sample ID & Lab ID & $\mathrm{Al}$ & $\mathrm{B}$ & $\mathrm{Gd}$ & $\mathrm{Hf}$ & $\mathrm{La}$ & $\mathrm{Nd}$ & $\mathrm{Si}$ & $\mathrm{Sr}$ & \\
\hline Frit X-06-1 (A) & $06-0981$ & 5.39 & 4.19 & 11.8 & 5.89 & 15.8 & 12.5 & 9.19 & 1.83 & \\
\hline Frit X-06-1 (B) & $06-0981$ & 5.39 & 4.13 & 11.0 & 5.54 & 15.2 & 12.3 & 9.52 & 1.88 & \\
\hline & & & & & & & & & & \\
\hline & & $\mathrm{Al}_{2} \mathrm{O}_{3}$ & $\mathrm{~B}_{2} \mathrm{O}_{3}$ & $\mathrm{Gd}_{2} \mathrm{O}_{3}$ & $\mathrm{HfO}_{2}$ & $\mathrm{La}_{2} \mathrm{O}_{3}$ & $\mathrm{Nd}_{2} \mathrm{O}_{3}$ & $\mathrm{SiO}_{2}$ & $\mathrm{SrO}$ & Total \\
\hline Frit X-06-1 (A) & $06-0981$ & 10.2 & 13.5 & 13.6 & 6.95 & 18.5 & 14.6 & 19.7 & 2.16 & 99.1 \\
\hline Frit X-06-1 (B) & $06-0981$ & 10.2 & 13.3 & 12.7 & 6.54 & 17.8 & 14.4 & 20.4 & 2.22 & 97.4 \\
\hline & & & & & & & & & & \\
\hline Average & & 10.2 & 13.4 & 13.1 & 6.74 & 18.1 & 14.5 & 20.0 & 2.19 & 98.3 \\
\hline Expected & & 10.0 & 13.0 & 13.5 & 7.00 & 19.0 & 15.0 & 20.0 & 2.50 & 100 \\
\hline & & & & & & & & & & \\
\hline & $\begin{array}{l}\text { Exp. / } \\
\text { Target }\end{array}$ & 1.02 & 1.03 & 0.97 & 0.96 & 0.95 & 0.97 & 1.00 & 0.88 & 0.98 \\
\hline
\end{tabular}

\subsection{SEM/EDS and XRD}

\subsubsection{As-Fabricated Glass}

A sample of the as-fabricated Pu-containing Frit X quenched glass was submitted for XRD and SEM analyses. The XRD analysis indicated that there was detectable crystalline $\mathrm{PuO}_{2}$ in the glass (Figure 3-1) as indicated by the four weak peak lines characteristic of crystalline $\mathrm{PuO}_{2}$. Previous work has shown that the nominal XRD detection limit of crystalline $\mathrm{PuO}_{2}$ in a powdered glass sample is about $0.2 \mathrm{wt} \%$ (Vienna, 1996). Consistent with the XRD scan, the SEM analyses showed the presence of some undissolved $\mathrm{PuO}_{2}$ particles with a disk-like morphology (Figure 3-2). This observation was consistent with previous microscopy analyses on Pu-loaded Frit X quenched glass and Pu-loaded Frit B quenched glass (Marra, 2006a and Marra, 2006b). The previous glasses were fabricated in the same manner using shaken/mixed powders, followed by two successive melt/quench steps. Microstructural analysis of the $\mathrm{PuO}_{2}$ starting material used in this study was not performed. However, the $\mathrm{PuO}_{2}$ powder used in the current work is similar in appearance to the $\mathrm{PuO}_{2}$ used for the Pu-loaded Frit B study (Marra, 2006a). In that work, $\mathrm{SEM}$ analysis of the $\mathrm{PuO}_{2}$ powder indicated that it was comprised of very fine nanometer-sized crystallites that formed larger agglomerates and that the starting $\mathrm{PuO}_{2}$ material was not the cause of the crystalline $\mathrm{PuO}_{2}$ observed in the quenched 
glass. We attribute the small amount of crystalline $\mathrm{PuO}_{2}$ in the as-fabricated $\mathrm{Pu}$ Frit $\mathrm{X}$ glasses to 'undissolved' $\mathrm{PuO}_{2}$, rather than $\mathrm{PuO}_{2}$ that has recrystallized from a homogeneous melt. It is expected that stirring and/or co-grinding of the frit and $\mathrm{PuO}_{2}$ would enhance dissolution and minimize the amount of undissolved $\mathrm{PuO}_{2}$ in the glass (Vienna, 1996).

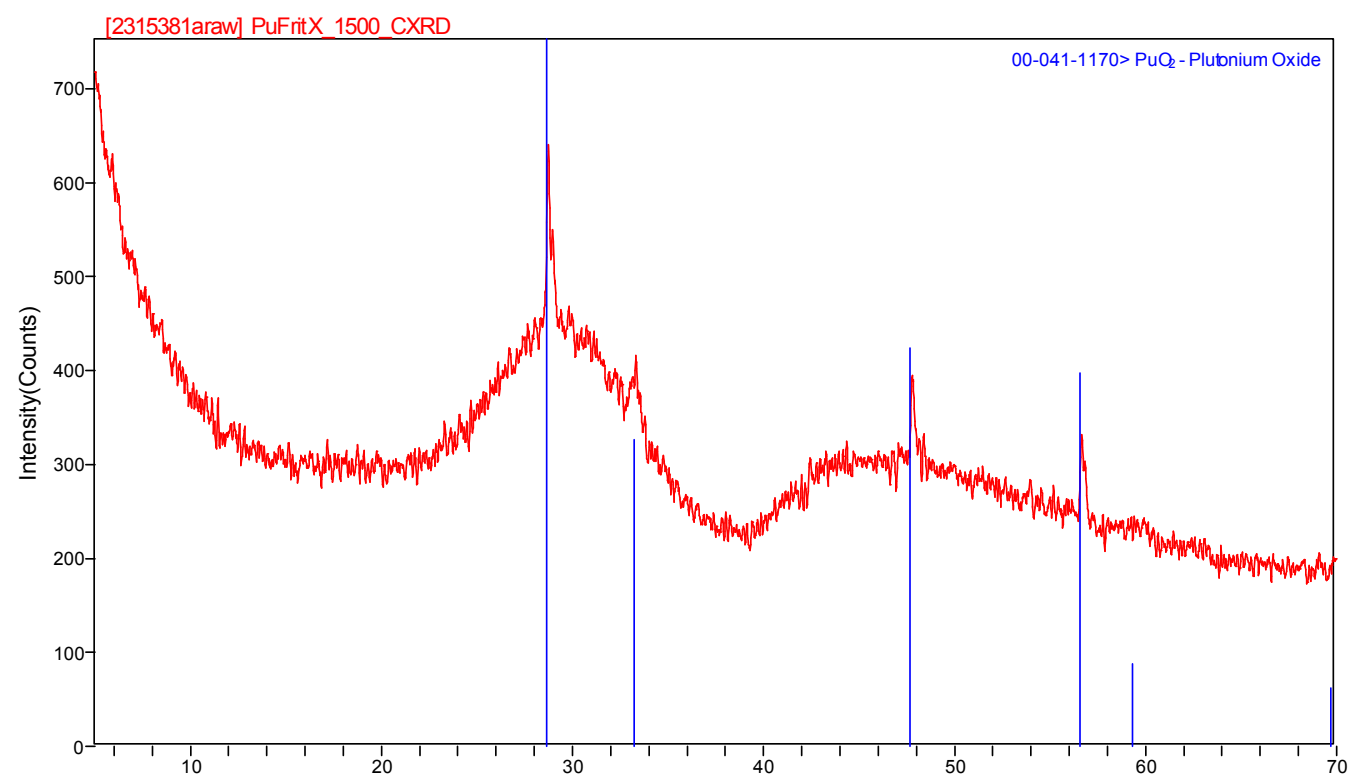

Figure 3-1. XRD scan of plutonium Frit $\mathrm{X}$ glass showing undissolved $\mathrm{PuO}_{2}$. 
WSRC-STI-2006-00318

Revision 0
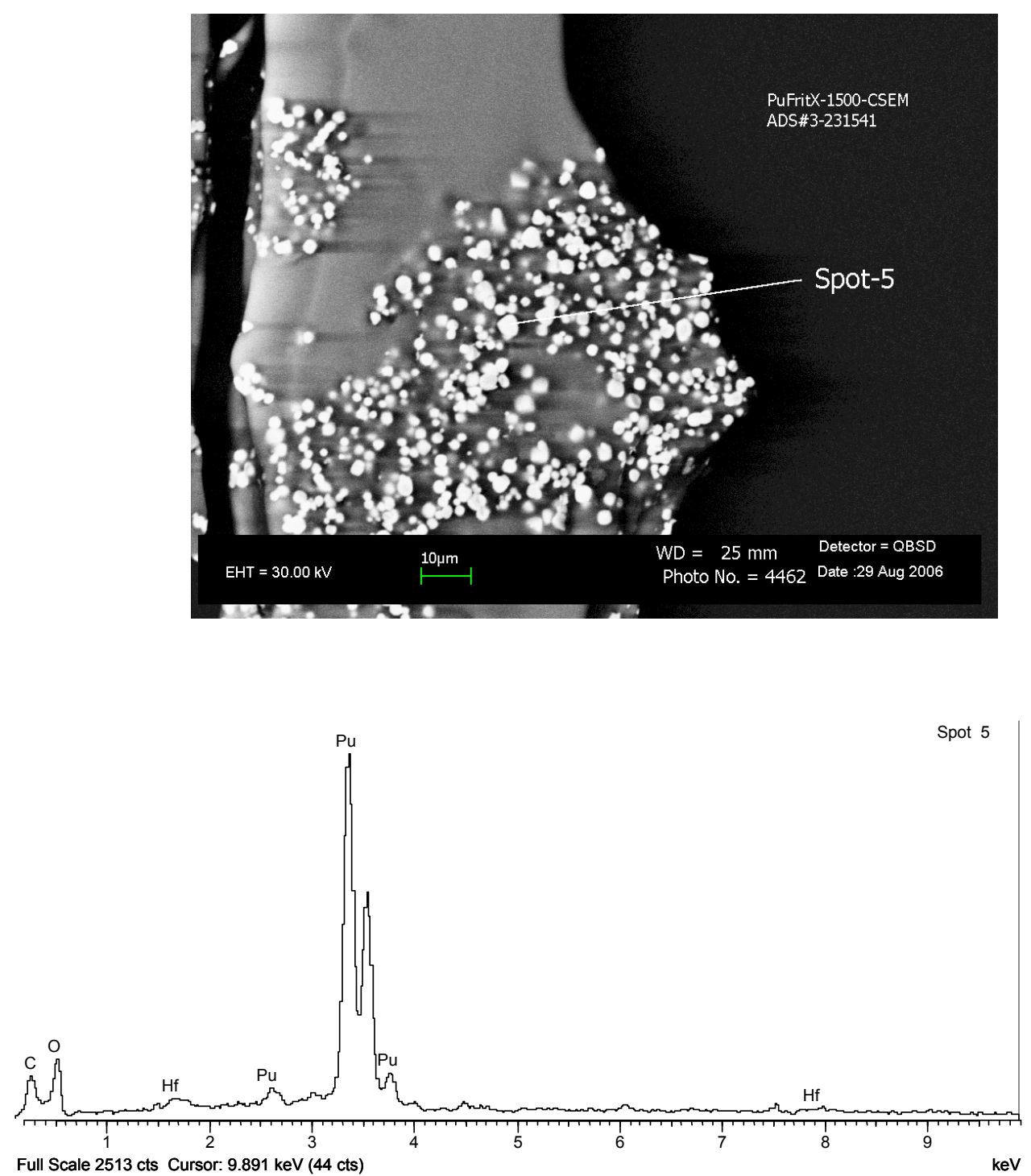

Figure 3-2. SEM micrograph and corresponding EDS spectra showing undissolved crystalline $\mathrm{PuO}_{2}$ in the as-fabricated Frit $\mathrm{X}$ glass. 


\subsubsection{Isothermal Heat-Treated Glasses}

The initial $\sim 1 \mathrm{~g} \mathrm{Pu}$ Frit $\mathrm{X}$ glass isothermal testing indicated that an isothermal hold temperature of $1250^{\circ} \mathrm{C}$ for nominally 4 hours was effective in crystallizing Pucontaining phases in addition to the $\mathrm{PuO}_{2}$ observed in the quenched glass. The XRD spectrum indicated the presence of $\mathrm{PuO}_{2}$ and neodymium hafnium oxide $\left(\mathrm{Nd}_{2} \mathrm{Hf}_{2} \mathrm{O}_{7}\right)$ (Figure 3-3). There was also evidence of peak shift in these spectra that is likely due to the presence of the $\mathrm{PuO}_{2}-\mathrm{HfO}_{2}$ solid solution phase. There was no match for these shifted peaks to any of the reference crystalline species available to the XRD instrument. The SEM/EDS analyses clearly indicated the presence of a phase containing both $\mathrm{Pu}$ and Hf (Figure 3-4). Efforts are currently underway to perform semi-quantitative compositional analysis of the $\mathrm{Pu}-\mathrm{Hf}$ phase using the EDS spectra. To facilitate these measurements a plutonium standard must first be developed, however. Previous studies have been performed on $\mathrm{Pu}-\mathrm{Zr}$ solid solution phases indicating that a single-phase facecentered cubic solid solution is evident from pure $\mathrm{PuO}_{2}$ up to 77 mole $\% \mathrm{ZrO}_{2}$ (Carroll, 1963). Since it is well known that $\mathrm{Zr}$ and $\mathrm{Hf}$ are extremely similar in chemical behavior (Speer, 1982), it seems reasonable to expect possibility of a $\mathrm{PuO}_{2}-\mathrm{HfO}_{2}$ solid solution.

Based on the results of the initial $1 \mathrm{~g}$ Pu Frit X glass heat treatment studies, a bulk Pu Frit $\mathrm{X}$ glass sample $(\sim 25 \mathrm{~g})$ was subjected to the $1250^{\circ} \mathrm{C}$ isothermal treatment profile. The $\mathrm{SEM} / \mathrm{EDS}$ analyses from this sample provided similar results (Figure 3-5).

It should be noted that the crystallization in the glass appeared in a "clustered" manner indicating the possibility that the $\mathrm{PuO}_{2}$ exists in clusters in the glass structure (Figure 3-5). Clustering of ions in glass has been hypothesized to occur in other glass systems (Brown et al., 1995). Alternatively, the observed crystalline $\mathrm{PuO}_{2}$ clustering could be a result of highly enriched $\mathrm{Pu}$ concentration clusters in the glass. This clustering effect should be studied in more detail to better understand the structural role of plutonium (and other cations) in the LaBS glass system.

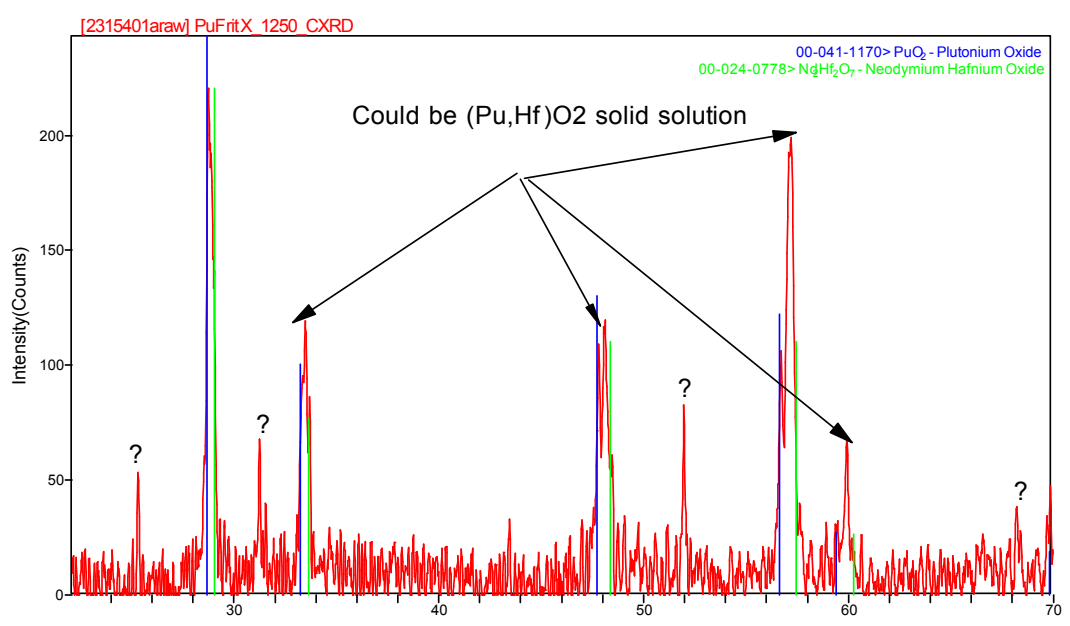

Figure 3-3. XRD scan of plutonium Frit $X$ glass thermally treated at $1250^{\circ} \mathrm{C}$. The apparent peak shift could be indicative of the presence of a $\mathrm{PuO}_{2}-\mathrm{HfO}_{2}$ solid solution phase. 

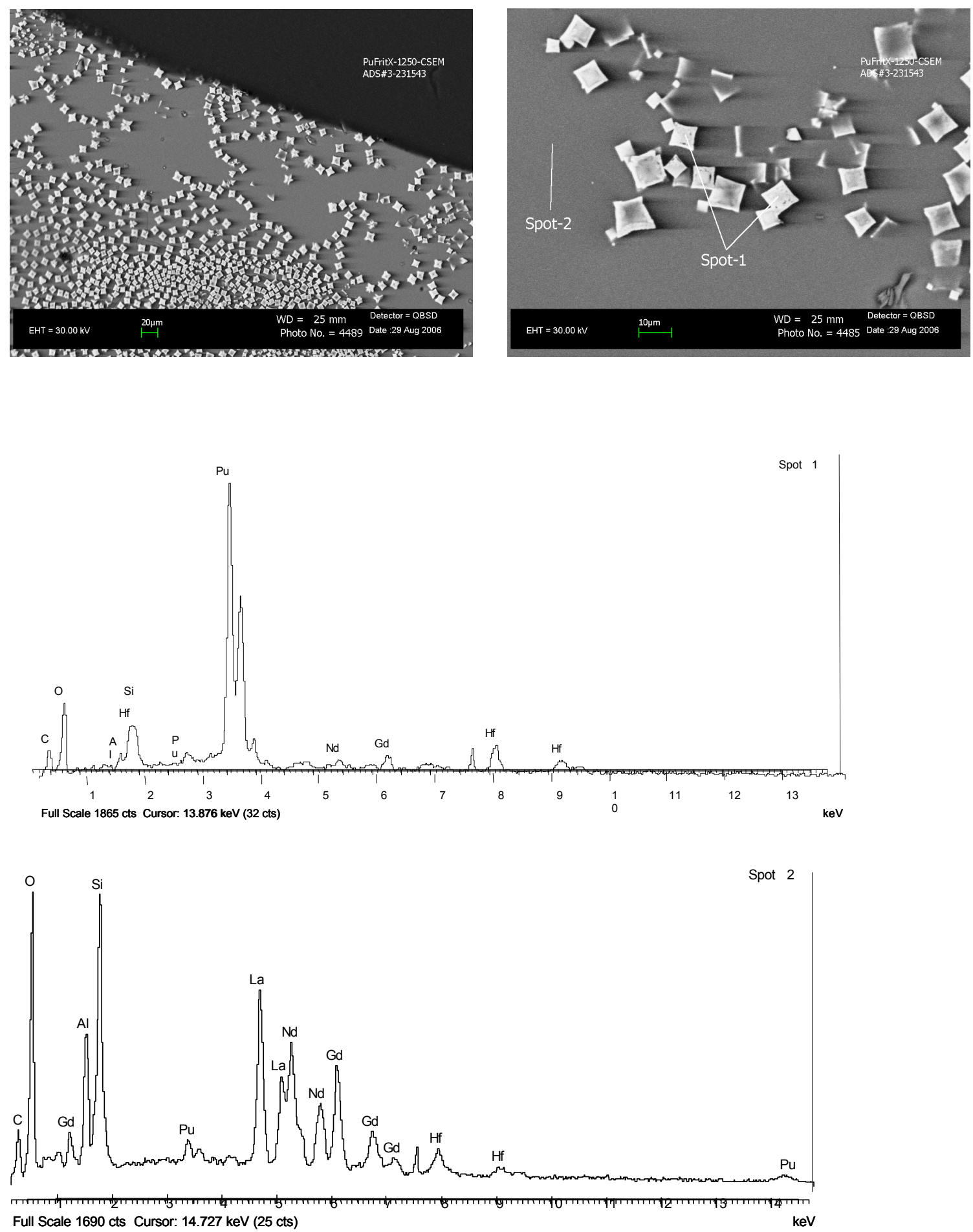

Figure 3-4. SEM micrograph and corresponding EDS spectra showing the presence of a proposed $\mathrm{PuO}_{2}-\mathrm{HfO}_{2}$ solid solution phase in the glass.

Spot 1 shows the composition of the crystalline phase. Spot 2 shows the composition of the matrix glass. 

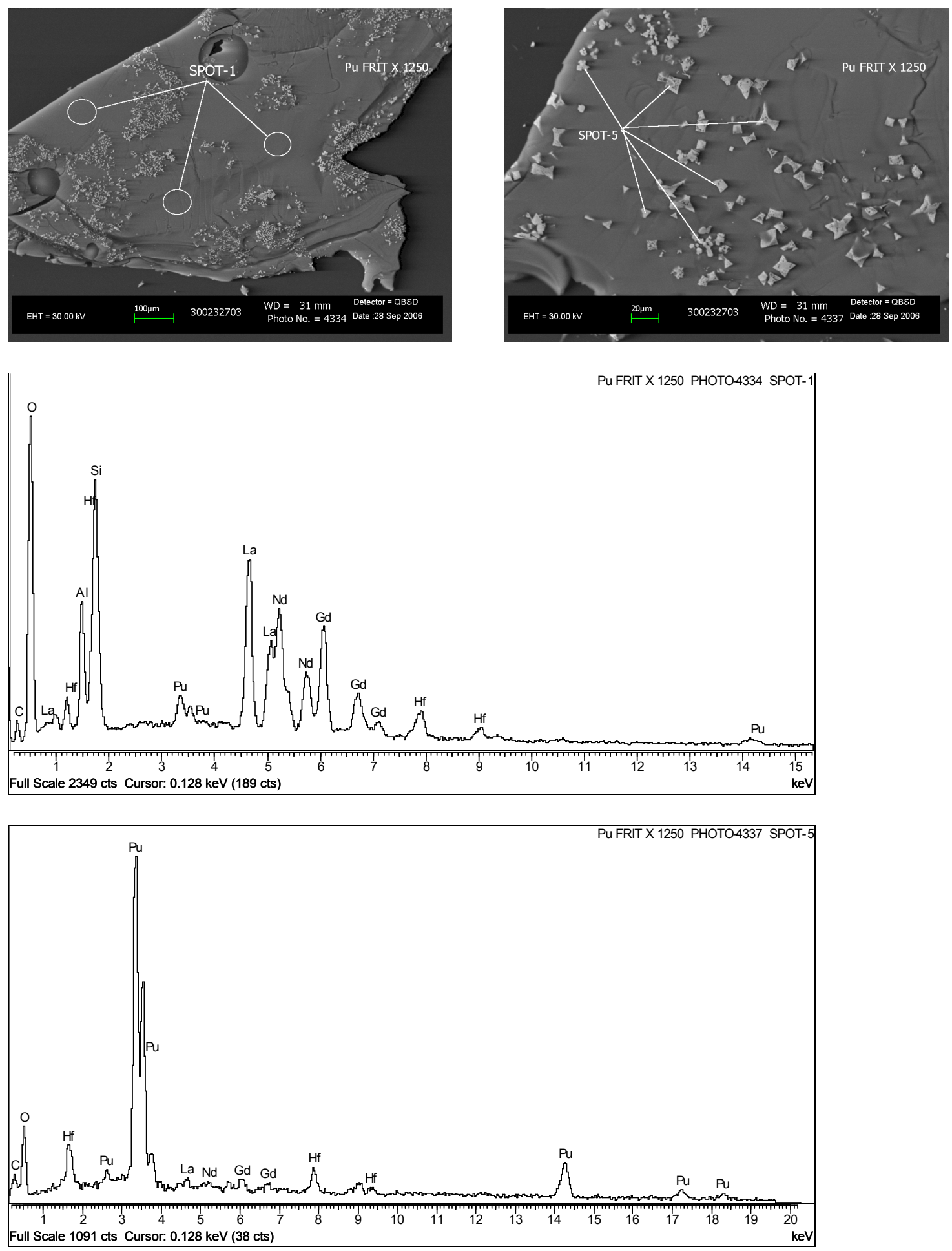

Figure 3-5. SEM micrograph and corresponding EDS spectra showing the presence of a proposed $\mathrm{PuO}_{2}-\mathrm{HfO}_{2}$ solid solution phase in the bulk heat-treated glass.

Spot 1 shows the composition of the matrix glass. Spot 5 shows the composition of the proposed solid solution phase. Note apparent clustering of the crystalline phase in the glass. 


\subsubsection{Can-in-Canister Thermal Profile Heat-Treated Glasses}

A shard from a bulk sample of the Pu Frit X glass ( $\sim 25 \mathrm{~g})$ that was subjected to a can-incanister thermal profile was also analyzed by XRD and SEM/EDS. The XRD spectra from this testing indicated the presence of both $\mathrm{PuO}_{2}$ and $\mathrm{Nd}_{2} \mathrm{Hf}_{2} \mathrm{O}_{7}$ in the glass (Figure 3-6). The SEM/EDS analyses showed that several phases had precipitated in the glass (Figure 3-7). These phases included a spherical $\mathrm{PuO}_{2}$ phase that appeared to range in size from submicron to $\sim 5$ micron (Spot 6), a dendritic-type phase that was comprised of mixed lanthanides (La, Nd, Gd) and plutonium (Spot 3), and a minor phase that contained $\mathrm{Pu}$ and $\mathrm{Hf}$ (Spot 4). It again should be noted that the observed crystalline phases were present as clusters within a matrix of vitreous glass. The spherical $\mathrm{PuO}_{2}$ phase is of particular interest from a product performance perspective. Preferential leaching of this phase and/or Pu colloid formation and transport could adversely impact the repository performance of the glass. Therefore, the leaching behavior of this glass is of particular interest (as will be discussed in Section 3.4).

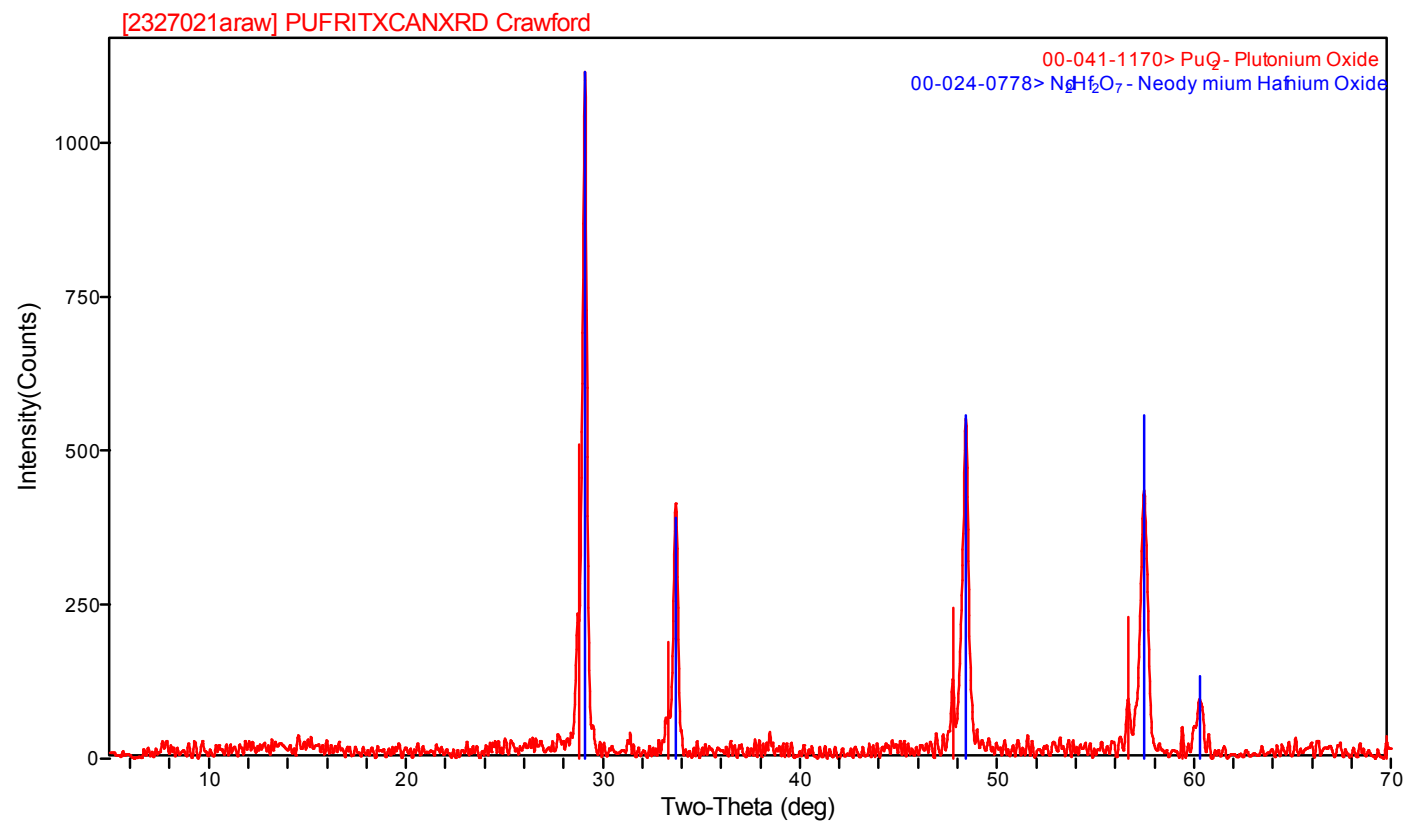

Figure 3-6. XRD Scan of Canister Thermal Profile Indicating Presence of Crystalline $\mathrm{PuO}_{2}$ and $\mathrm{Nd}_{2} \mathrm{Hf}_{2} \mathrm{O}_{7}$ in the Glass 

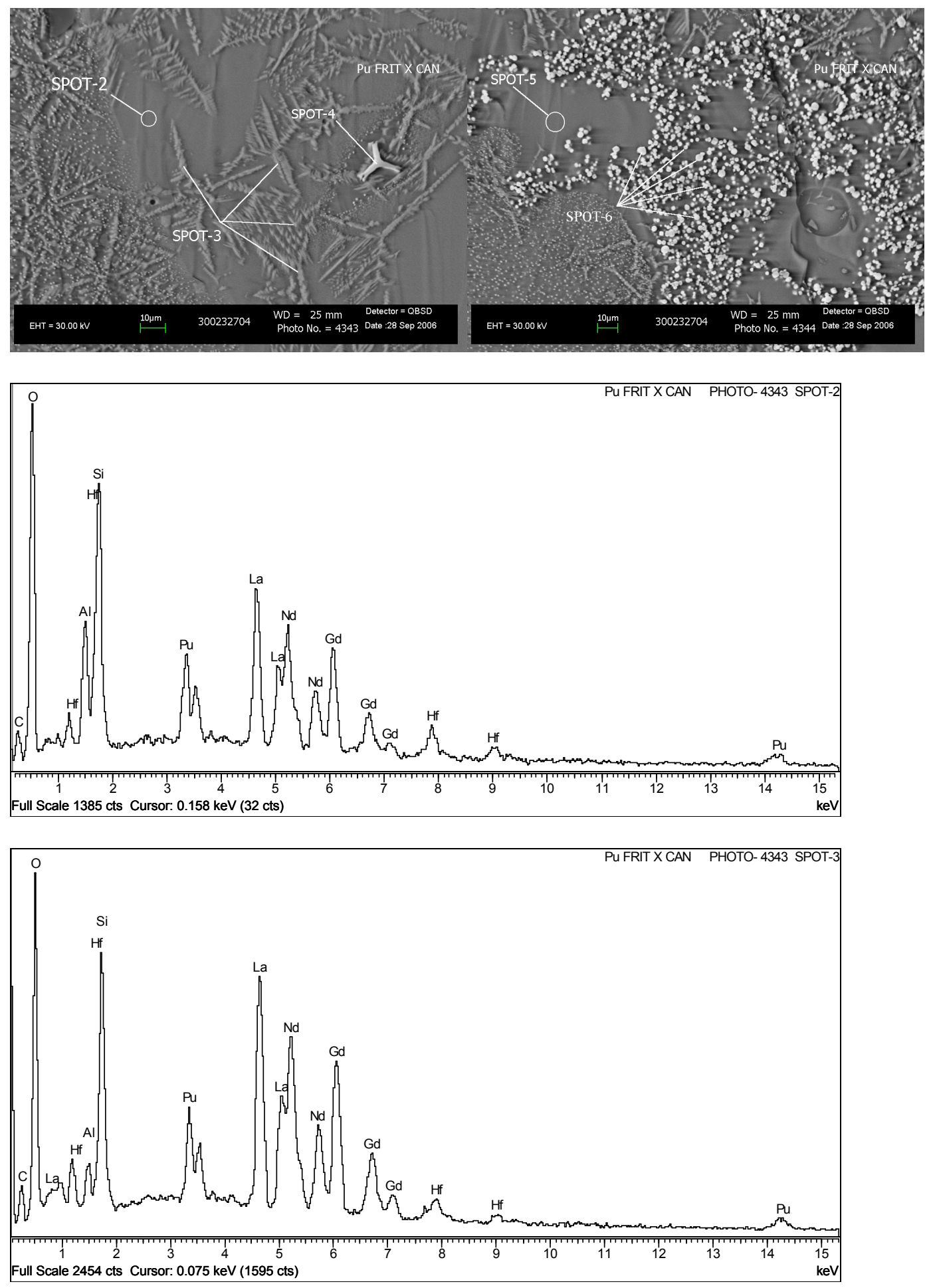

Figure 3-7. SEM micrograph and corresponding EDS spectra showing the presence of multiple crystalline phases in the canister thermal treatment glass.

Spots 2 and 5 show the composition of the matrix glass. Spots 3, 4 and 6 show the composition of the various crystalline phases. 
WSRC-STI-2006-00318

Revision 0
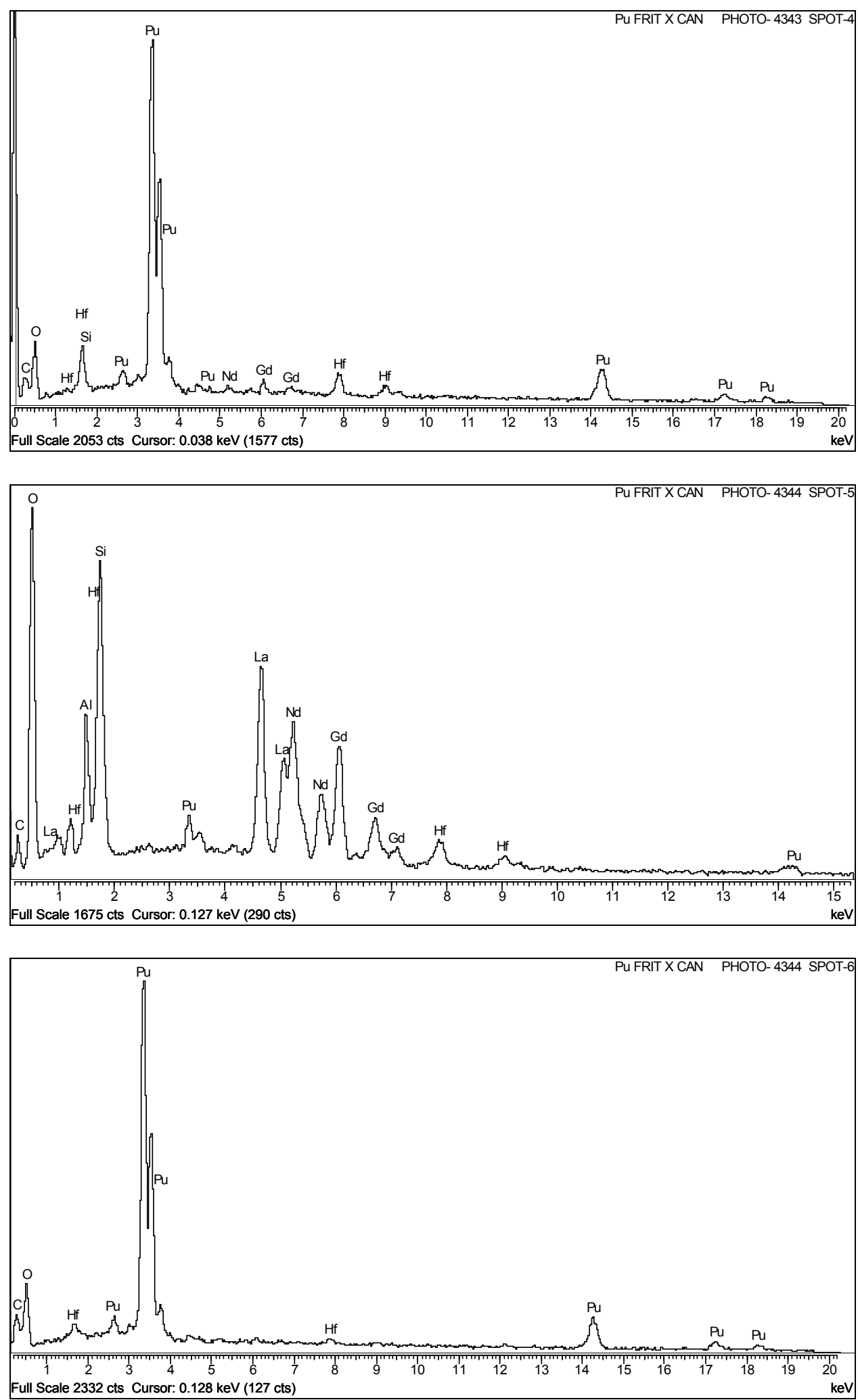

Figure 3-7. SEM micrograph and corresponding EDS spectra showing the presence of multiple crystalline phases in the canister thermal treatment glass. - continued 


\subsection{Results of the PCT-A and PCT-B on As-Fabricated (Quenched) Glass}

Both the PCT-A and the PCT-B type tests were performed on the Pu LaBS glass prepared with Frit X. Table 3-2 shows a summary of the various PCT's performed on the Pu Frit $\mathrm{X}$ LaBS glass that was quenched. The first three tests are PCT-A conditions (Samples $\mathrm{PuX}-1, \mathrm{PuX}-2$ and PuX-3). The blank tests performed with ASTM-1 water were also included for comparison. The second three tests are PCT-B conditions (Samples PuX-4, $\mathrm{PuX}-5$ and PuX-6) because they were not prepared at the 1:10 glass mass to leachant volume specified in PCT-A. Details for the EA and ARM-1 glass are also shown. The ' $\mathrm{SA} / \mathrm{V}$ ' column in Table 3-2 shows that for PCT-A conditions with the Pu Frit X glass, the calculated SA/V values are about $1250 \mathrm{~m}^{-1}$, whereas the EA and ARM-1 glass PCT-A $\mathrm{SA} / \mathrm{V}$ values are $\sim 2,000 \mathrm{~m}^{-1}$. All tests were performed remotely in the SCF of SRNL. The PCTs performed in steel vessels used a wrench and holder system to tighten the vessels. The total water mass loss during the 7 -day test was well below the allowable $5 \%$ of total starting leachant mass.

The surface area of the 100 to 200 mesh $(0.149 \mathrm{~mm}$ to $0.074 \mathrm{~mm})$ powdered glasses was calculated using the following formula:

$$
\mathrm{SA}\left(\mathrm{m}^{2}\right)=\text { glass mass } *(1 /(\text { avg. particle mass })) *(\text { surface area/particle })
$$

with, glass mass = mass of powdered glass sample used in each test, average particle mass $=$ glass density $*$ volume/particle, glass density $=4.3 \mathrm{E} 6 \mathrm{~g} / \mathrm{m}^{3}$ for Pu Frit X and nominally $2.7 \mathrm{E} 6 \mathrm{~g} / \mathrm{m}^{3}$ for EA and ARM-1, volume $/$ particle $=7.25 \mathrm{E}-13 \mathrm{~m}^{3} /$ particle (from ASTM PCT Procedure), surface area/particle $=3.9 \mathrm{E}-8 \mathrm{~m}^{2} /$ particle (from ASTM PCT Procedure).

The density of Pu Frit X glass is assumed to be similar to the previously measured density of the Frit X (Marra, 2006b). Both EA and ARM-1 glass densities are assumed to be similar to $2.7 \mathrm{E} 6 \mathrm{~g} / \mathrm{m}^{3}$ for HLW glasses per the ASTM PCT Procedure. The volume/particle and surface area/particle are based on an assumed average diameter of a spherical particle of $1.12 \mathrm{E}-4 \mathrm{~m}$ from the ASTM Procedure.

The surface area to volume data shown in Table 3-2 can be calculated with the starting volumes (column labeled 'SA/V') and the final volumes, i.e., the effective SA/V (column labeled 'Effective $\mathrm{SA} / \mathrm{V}$ '), that take into account minor leachate mass losses during the 7 -day test.

Concentration and $\mathrm{pH}$ data for the filtered leachates are shown in Table 3-3 in units of $\mathrm{mg} / \mathrm{L}$. Data shown with 'less than' values $(<)$ were below the instrument method detection limits times the appropriate dilution factor correction. The Pu Frit X glass leachates and the ARM-1 leachates were diluted $3 \mathrm{~mL}$ of leachate to $10.1 \mathrm{~mL}$ total $(7 \mathrm{~mL}$ of water, $3 \mathrm{~mL}$ of leachate and $0.1 \mathrm{~mL}$ of nitric acid). This gives a dilution factor correction of $10.1 / 3=3.37$. 
The EA glass leachates were diluted more, using $0.5 \mathrm{~mL}$ of leachate to $10.1 \mathrm{~mL}$ total, or a dilution correction factor of 20.2. The blank solutions were not diluted except for the 0.1 $\mathrm{mL}$ of acid added to $6 \mathrm{~mL}$, giving a dilution factor correction of 1.02 . No detectable $\mathrm{Al}$, $\mathrm{B}, \mathrm{Si}, \mathrm{Sr}$ or Li was present in the blanks. Only one blank leachate was submitted for ICPMS and it showed no detectable amounts for $\mathrm{La}, \mathrm{Nd}, \mathrm{Gd}, \mathrm{Hf}$ and $\mathrm{Pu}$. There was not detectable $\mathrm{Hf}$ in any of the Pu Frit X glass leachates. One of the PCT-A leachates (PuX3) appears to be higher than the other $\mathrm{PuX}-1$ and $\mathrm{PuX}-2$ replicates for most elements ( $\mathrm{Al}$, $\mathrm{B}, \mathrm{Sr}, \mathrm{La}, \mathrm{Nd}, \mathrm{Gd}$ and $\mathrm{Pu}$ ). This high bias could be due to contamination from a small particle of glass in perhaps the leachate filtration step.

The $\mathrm{pH}$ values for the Pu Frit X glass leachates ranged from 6.2 to 6.9 and were not significantly changed from the starting neutral ASTM-1 water leachant values in the range of 6.6 to 6.9. The blank leachates were also neutral with $\mathrm{pH}$ of $\sim 7.0$. The EA leachate $\mathrm{pH}$ 's were in the range of 11.65 to 11.75 , which is in good agreement with published data in the range of 11.7 to 12.0, or an average of 11.85 (Jantzen, 1993). Comparison of the concentrations for the ARM-1 glass vs. control chart historical ranges (Jantzen, 1995) shown at the bottom of Table 3-3 indicates that the average B release is just within the upper range while measured $\mathrm{Si}, \mathrm{Li}$ and $\mathrm{Na}$ releases are slightly higher. Comparison of ICP-AES analyzed multielement standards (MES) shown at the bottom of Table 3-3, submitted along with the leachates indicates that average MES analyses agree with target to within $\pm 4 \%$.

Concentration data for the acid strip solutions are shown in Table 3-4 in units of mg/L. Aluminum was the only element detected in the ICP-AES acid strip analyses. Data reported for B, Si and Sr as 'less than' values are slightly lower than 'less than' values reported for the leachates because the acid strip solutions were not diluted prior to submission for analyses. Some Al was detected in the blank strip solutions. There are $\mu \mathrm{g} / \mathrm{L}$ (ppb) and sub-ppb levels of La, Nd, Hf and Pu detected in the blanks for ICP-MS, but no detectable Gd. The acid strip volumes are also shown in Table 3-4. The low and 'less than' values for the acid strip solution data for Al, B, Si and Sr indicates that the steel vessels were adequately rinsed to remove any micron-sized glass particles before the acid strip was performed. These glass elements when leached into solution are not expected to adhere to the inside of the steel vessels like certain radionuclides and redox sensitive elements identified in the PCT procedure. All of the ICP-MS elements La, Nd, $\mathrm{Gd}$, Hf and $\mathrm{Pu}$ were detected in the Pu Frit X strip solutions. 
The concentration data shown for the leachates and the acid strip solutions were used to calculate the normalized mass loss in terms of grams of glass leached per square meter $\left(\mathrm{g} / \mathrm{m}^{2}\right)$ using the following equation.

$\mathrm{NL}_{\mathrm{i}}=\mathrm{m}_{\mathrm{i}}($ sample $) /\left(\left(\mathrm{f}_{\mathrm{i}}\right) \times(\mathrm{SA})\right)$

Where: $\mathrm{NL}_{\mathrm{i}}$ is normalized release based on element $\mathrm{i}$, in grams of glass leached per square meter of glass exposed in the PCT, $\mathrm{m}_{\mathrm{i}}$ (sample) is the combined mass of the $\mathrm{i}^{\text {th }}$ element in leachate and acid strip, or $\left(\left(\mathrm{c}_{\mathrm{i}}(\right.\right.$ leachate $) \mathrm{x}$ final vol. leachate $)+\left(\mathrm{c}_{\mathrm{i}}(\mathrm{strip}) \mathrm{x}\right.$ vol. strip $\left.)\right)$

$\mathrm{c}_{\mathrm{i}}$ (leachate) are the measured solution values $\mathrm{c}_{\mathrm{i}}$ (strip) are the measured acid strip solution values $\mathrm{f}_{\mathrm{i}}$ is the fraction of element $\mathrm{i}$ in the unleached glass (unitless) $\mathrm{SA}$ is the surface area of the powdered glass sample

In the $\mathrm{NL}_{\mathrm{i}}$ equation above, the $\mathrm{m}_{\mathrm{i}}$ (sample) terms were blank-corrected if there were detectable amounts of element $i$ in either the leachate blank solutions or the acid strip blank solutions. Values used for the $\mathrm{f}_{\mathrm{i}}$ term for the Pu Frit X glasses are taken from the experimental values determined from the Pu Frit $\mathrm{X}$ frit analyses shown earlier in Section 3.1 (adjusted for addition of $9.5 \mathrm{wt} \% \mathrm{PuO}_{2}$ ).

Table 3-5 shows the calculated normalized release values for the Pu Frit X glasses at the two different SA/V ratios, and the normalized release for the EA glass. Values shown with a 'less than' sign indicate that the leachate and/or the strip solution was an upper bound, thus making the calculated normalized release value an upper bound. Several values for the Al, B, Si and Sr normalized release rates for the Pu Frit X glass are upper bounds. Only the Hf values are upper bounds for the ICP-MS data. Average normalized releases are shown for the Pu Frit X glass as well as standard deviations and percent relative standard deviation. Upper bound values were used in the averages. The standard deviation values are calculated from the triplicate data throughout this report using the Microsoft ${ }^{\circledR}$ Excel 'STDEV' function. This function that calculates the standard deviation from a small number $(<30)$ of samples is:

$$
\begin{aligned}
& \hline \mathrm{s}=\left[\left(\mathrm{n} \sum \mathrm{x}^{2}-\left(\sum \mathrm{x}\right)^{2}\right) / \mathrm{n}(\mathrm{n}-1)\right]^{0.5} \\
& \text { with } \quad \begin{array}{l}
\mathrm{n}=3 \text { for the triplicate set } \\
\mathrm{x}=\text { value of each individual measurement }
\end{array}
\end{aligned}
$$

The standard deviation calculated from the function above for small numbered data sets can be associated with the standard deviation or 'sigma' values $(\sigma)$ commonly used to specify a confidence level for a data set. The average \pm one standard deviation gives a confidence level of $68 \%$ whereas the average \pm two standard deviations gives a confidence level of $95 \%$. 
A 'less than' sign is shown for the average if all three replicates were also 'less than' values. Comparison of the normalized elemental release rates for the Pu Frit $\mathrm{X}$ glass PCT-A $\left(\mathrm{SA} / \mathrm{V}=1250 \mathrm{~m}^{-1}\right)$ vs. PCT-B $\left(\mathrm{SA} / \mathrm{V}=2000 \mathrm{~m}^{-1}\right)$ indicates no significant differences in normalized release. In data sets with no 'less than' values reported, the $\%$ RSD values are less than $15 \%$ indicating good precision in the triplicate values.

Measured normalized release rates for the EA glass in this PCT are averaged and compared to literature values (Jantzen, 1993). The measured averages for B, $\mathrm{Si}, \mathrm{Li}$ and $\mathrm{Na}$ are slightly higher than the literature averages but all average measured values (except for B) are within the literature average plus one standard deviation. Comparison of the PCT-A data for Pu Frit X glass vs. the EA glass data shows that the average normalized release for the $\mathrm{Pu}$ Frit $\mathrm{X}$ glass is $>300$ times lower based on $\mathrm{B}$ and $>30$ times lower based on Si. Thus the Pu Frit X glass meets the durability criterion stated in the WAPS for HLW glass. 
WSRC-STI-2006-00318

Revision 0

Table 3-2. Summary of PCTs Performed on Quenched Pu Frit X Glass

\begin{tabular}{|c|c|c|c|c|c|c|c|c|c|c|c|c|c|}
\hline $\begin{array}{c}\text { PCT } \\
\text { Method }\end{array}$ & Vessel ID & $\begin{array}{c}\text { Sample } \\
\text { ID }\end{array}$ & $\begin{array}{c}\text { Glass } \\
\text { Mass (g) }\end{array}$ & $\begin{array}{c}\text { Starting } \\
\text { Leachant } \\
\text { Mass }(\mathrm{g})\end{array}$ & $\begin{array}{c}\text { Ratio } \\
\text { Leachant } \\
\text { to Glass }\end{array}$ & $\begin{array}{l}\text { Calculated } \\
\text { Surface } \\
\text { Area }\left(\mathrm{m}^{\wedge} 2\right)\end{array}$ & $\begin{array}{c}\mathrm{SA} / \mathrm{V} \\
\left(\mathrm{m}^{\wedge}-1\right)\end{array}$ & $\begin{array}{c}\text { PCT } \\
\text { Duration } \\
\text { (Days) }\end{array}$ & $\begin{array}{c}\text { Total } \\
\text { Mass } \\
\text { Loss (g) }\end{array}$ & $\begin{array}{c}\text { Effective } \\
\mathrm{SA} / \mathrm{V}\left(\mathrm{m}^{\wedge}-\right. \\
1)\end{array}$ & $\begin{array}{l}\text { \% Leachate } \\
\text { Mass Loss }\end{array}$ & $\begin{array}{c}\text { Avg. } \\
\text { Leachate } \\
\text { Mass Loss } \\
\text { per Day } \\
\text { (g/day) }\end{array}$ & $\begin{array}{c}\text { Final } \\
\text { Leachate } \\
\text { Mass (g) }\end{array}$ \\
\hline PCT-A & P320 & PuX-1 & 1.004 & 10.057 & 10.02 & $1.25 \mathrm{E}-02$ & 1246 & 7 & 0.031 & 1250 & 0.3 & 0.004 & 10.026 \\
\hline PCT-A & P361 & $\mathrm{PuX}-2$ & 1.028 & 10.281 & 10.00 & $1.28 \mathrm{E}-02$ & 1248 & 7 & 0.023 & 1251 & 0.2 & 0.003 & 10.258 \\
\hline PCT-A & 394 & PuX-3 & 1.004 & 10.033 & 9.99 & $1.25 \mathrm{E}-02$ & 1249 & 7 & 0.027 & 1252 & 0.3 & 0.004 & 10.006 \\
\hline PCT-A & 545 & Blk-1 & 0 & 17.955 & NA & NA & $\mathrm{NA}$ & 7 & 0.026 & NA & 0.1 & 0.004 & 17.929 \\
\hline PCT-A & 546 & Blk-2 & 0 & 17.984 & NA & NA & NA & 7 & 0.028 & NA & 0.2 & 0.004 & 17.956 \\
\hline PCT-B & 401 & PuX-4 & 1.503 & 9.45 & 6.29 & $1.88 \mathrm{E}-02$ & 1985 & 7 & 0.025 & 1990 & 0.3 & 0.004 & 9.425 \\
\hline PCT-B & 410 & PuX-5 & 1.502 & 9.464 & 6.30 & $1.87 \mathrm{E}-02$ & 1981 & 7 & 0.117 & 2006 & 1.2 & 0.017 & 9.347 \\
\hline PCT-B & 413 & PuX-6 & 1.511 & 9.448 & 6.25 & $1.89 \mathrm{E}-02$ & 1996 & 7 & 0.02 & 2000 & 0.2 & 0.003 & 9.428 \\
\hline PCT-A & 532 & ARM-1 & 1.600 & 16.012 & 10.01 & $3.19 \mathrm{E}-02$ & 1991 & 7 & 0.026 & 1994 & 0.2 & 0.004 & 15.986 \\
\hline PCT-A & 534 & ARM-2 & 1.610 & 16.096 & 10.00 & $3.21 \mathrm{E}-02$ & 1993 & 7 & 0.024 & 1996 & 0.1 & 0.002 & 16.072 \\
\hline PCT-A & 538 & ARM-3 & 1.611 & 16.135 & 10.02 & $3.21 \mathrm{E}-02$ & 1989 & 7 & 0.017 & 1991 & 0.1 & 0.002 & 16.118 \\
\hline PCT-A & 538 & EA-1 & 1.606 & 16.089 & 10.02 & $3.20 \mathrm{E}-02$ & 1989 & 7 & 0.026 & 1992 & 0.2 & 0.004 & 16.063 \\
\hline PCT-A & 538 & EA-2 & 1.597 & 15.917 & 9.97 & $3.18 \mathrm{E}-02$ & 1999 & 7 & 0.025 & 2002 & 0.2 & 0.002 & 15.892 \\
\hline PCT-A & 538 & EA-3 & 1.607 & 16.047 & 9.99 & $3.20 \mathrm{E}-02$ & 1995 & 7 & 0.032 & 1999 & 0.2 & 0.001 & 16.015 \\
\hline
\end{tabular}


WSRC-STI-2006-00318

Revision 0

Table 3-3. Concentration and pH Data for the Filtered Leachates from Quenched Pu Frit X Glasses

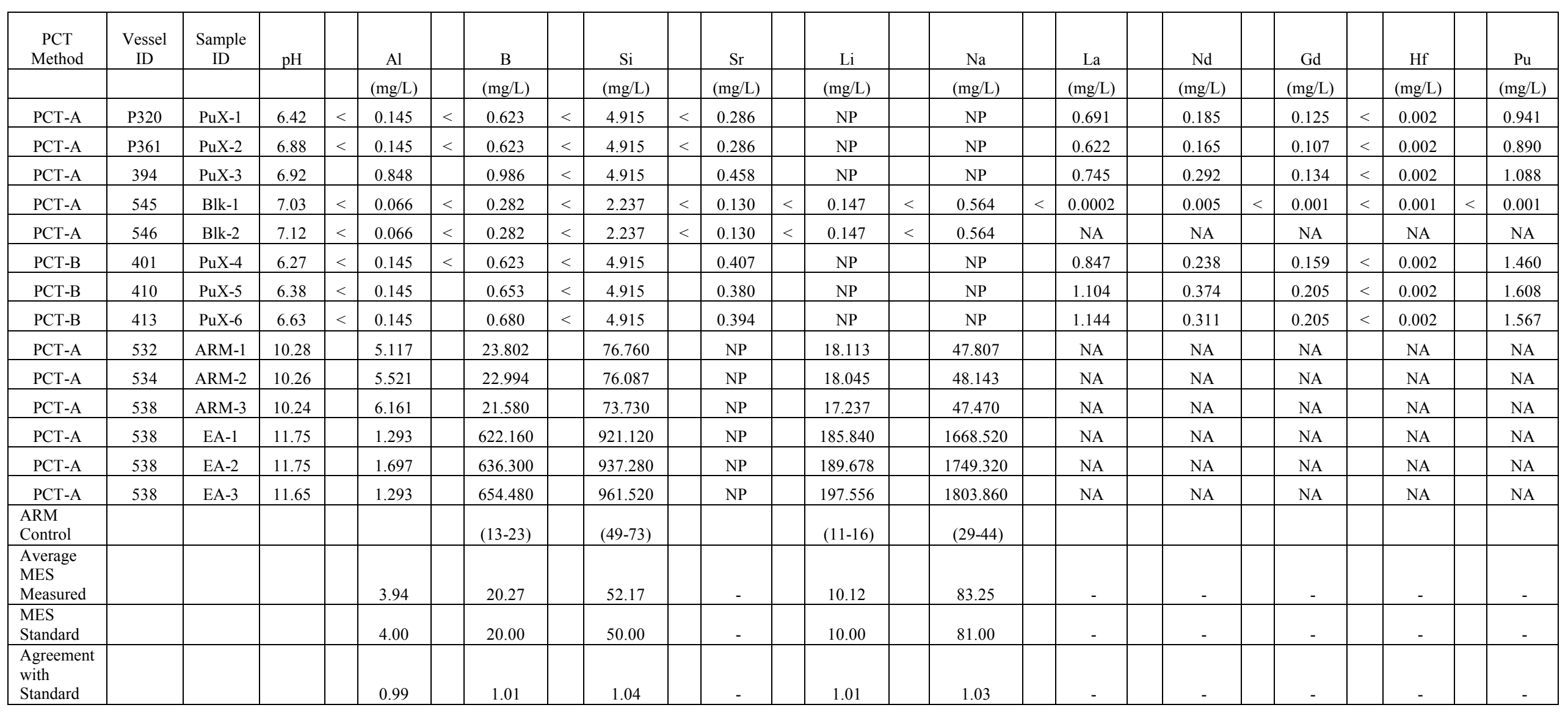

Notes:

$\mathrm{NP}=$ not present

$\mathrm{NA}=$ not analyzed 
WSRC-STI-2006-00318

Revision 0

Table 3-4. Concentration Data for the Acid Strip Solutions from Quenched Pu Frit X Glasses

\begin{tabular}{|c|c|c|c|c|c|c|c|c|c|c|c|c|c|c|c|c|}
\hline $\begin{array}{c}\text { PCT } \\
\text { Method }\end{array}$ & $\begin{array}{l}\text { Vessel } \\
\text { ID } \\
\end{array}$ & Sample ID & $\begin{array}{c}\text { Strip } \\
\text { Volume }\end{array}$ & $\mathrm{Al}$ & & $\mathrm{B}$ & & $\mathrm{Si}$ & & $\mathrm{Sr}$ & $\mathrm{La}$ & $\mathrm{Nd}$ & & $\mathrm{Gd}$ & $\mathrm{Hf}$ & $\mathrm{Pu}$ \\
\hline & & & $(\mathrm{mL})$ & $(\mathrm{mg} / \mathrm{L})$ & & $(\mathrm{mg} / \mathrm{L})$ & & $(\mathrm{mg} / \mathrm{L})$ & & $(\mathrm{mg} / \mathrm{L})$ & $(\mathrm{mg} / \mathrm{L})$ & $(\mathrm{mg} / \mathrm{L})$ & & $(\mathrm{mg} / \mathrm{L})$ & $(\mathrm{mg} / \mathrm{L})$ & $(\mathrm{mg} / \mathrm{L})$ \\
\hline PCT-A & P320 & PuX-1 & 18.242 & 0.356 & $<$ & 0.185 & $<$ & 1.460 & $<$ & 0.085 & 0.333 & 0.285 & & 0.254 & 0.077 & 0.243 \\
\hline Blnk.Corr. & & & & 0.247 & & & & & & & 0.331 & 0.282 & & 0.254 & 0.076 & 0.242 \\
\hline PCT-A & $\mathrm{P} 361$ & $\mathrm{PuX}-2$ & 18.229 & 0.314 & $<$ & 0.185 & $<$ & 1.460 & $<$ & 0.085 & 0.309 & 0.272 & & 0.240 & 0.077 & 0.232 \\
\hline Blnk.Corr. & & & & 0.205 & & & & & & & 0.307 & 0.268 & & 0.240 & 0.076 & 0.232 \\
\hline PCT-A & 394 & PuX-3 & 18.26 & 0.392 & $<$ & 0.185 & $<$ & 1.460 & $<$ & 0.085 & 0.326 & 0.276 & & 0.246 & 0.073 & 0.197 \\
\hline Blnk.Corr. & & & & 0.283 & & & & & & & 0.323 & 0.272 & & 0.246 & 0.072 & 0.197 \\
\hline PCT-A & 545 & Blk-1 & 18.2 & 0.159 & $<$ & 0.185 & $<$ & 1.460 & $<$ & 0.085 & 0.0031 & 0.0048 & $<$ & 0.003 & 0.0009 & 0.0003 \\
\hline PCT-A & 546 & Blk-2 & 18.2 & 0.077 & $<$ & 0.185 & $<$ & 1.460 & $<$ & 0.085 & 0.0018 & 0.0023 & $<$ & 0.002 & 0.0008 & 0.0004 \\
\hline PCT-B & 401 & $\mathrm{PuX}-4$ & 18.247 & 0.254 & $<$ & 0.185 & $<$ & 1.460 & $<$ & 0.085 & 0.188 & 0.172 & & 0.154 & 0.028 & 0.152 \\
\hline Blnk.Corr. & & & & 0.145 & & & & & & & 0.186 & 0.168 & & 0.154 & 0.027 & 0.152 \\
\hline PCT-B & 410 & PuX-5 & 18.245 & 0.240 & $<$ & 0.185 & $<$ & 1.460 & $<$ & 0.085 & 0.097 & 0.096 & & 0.083 & 0.014 & 0.082 \\
\hline Blnk.Corr. & & & & 0.131 & & & & & & & 0.094 & 0.093 & & 0.083 & 0.014 & 0.082 \\
\hline PCT-B & 413 & PuX-6 & 18.24 & 0.367 & $<$ & 0.185 & $<$ & 1.460 & $<$ & 0.085 & 0.200 & 0.181 & & 0.163 & 0.036 & 0.131 \\
\hline Blnk.Corr. & & & & 0.258 & & & & & & & 0.198 & 0.178 & & 0.163 & 0.035 & 0.131 \\
\hline
\end{tabular}


WSRC-STI-2006-00318

Revision 0

Table 3-5. Normalized Release Values for Pu Frit X Quenched Glasses and EA Glass

\begin{tabular}{|c|c|c|c|c|c|c|c|c|c|c|c|c|c|c|}
\hline & & $\mathrm{Al}$ & & $\mathrm{B}$ & & $\mathrm{Si}$ & & $\mathrm{Sr}$ & $\mathrm{La}$ & $\mathrm{Nd}$ & $\mathrm{Gd}$ & & $\mathrm{Hf}$ & $\mathrm{Pu}$ \\
\hline & & $\mathrm{g} / \mathrm{m}^{\wedge} 2$ & & $\mathrm{~g} / \mathrm{m}^{\wedge} 2$ & & $\mathrm{~g} / \mathrm{m}^{\wedge} 2$ & & $\mathrm{~g} / \mathrm{m}^{\wedge} 2$ & $\mathrm{~g} / \mathrm{m}^{\wedge} 2$ & $\mathrm{~g} / \mathrm{m}^{\wedge} 2$ & $\mathrm{~g} / \mathrm{m}^{\wedge} 2$ & & $\mathrm{~g} / \mathrm{m}^{\wedge} 2$ & $\mathrm{~g} / \mathrm{m}^{\wedge} 2$ \\
\hline $\mathrm{Pu}-1$ & $<$ & 0.00967 & $<$ & 0.02021 & $<$ & 0.07091 & $<$ & 0.02082 & 0.00731 & 0.00493 & 0.00452 & $<$ & 0.00214 & 0.01317 \\
\hline $\mathrm{Pu}-2$ & $<$ & 0.01073 & $<$ & 0.02003 & $<$ & 0.07028 & $<$ & 0.02063 & 0.00660 & 0.00453 & 0.00409 & $<$ & 0.00211 & 0.01239 \\
\hline $\mathrm{Pu}-3$ & & 0.02870 & $<$ & 0.02783 & $<$ & 0.07084 & & 0.02889 & 0.00753 & 0.00556 & 0.00448 & $<$ & 0.00203 & 0.01377 \\
\hline Avg. & & 0.0164 & $<$ & 0.0227 & $<$ & 0.0707 & & 0.0234 & 0.0071 & 0.0050 & 0.0044 & $<$ & 0.0021 & 0.0131 \\
\hline St.dev. & & 0.0107 & & 0.0045 & & 0.0003 & & 0.0047 & 0.0005 & 0.0005 & 0.0002 & & 0.0001 & 0.0007 \\
\hline$\%$ RSD & & 65.4 & & 19.6 & & 0.5 & & 20.1 & 6.8 & 10.4 & 5.4 & & 2.7 & 5.3 \\
\hline $\mathrm{Pu}-4$ & $<$ & 0.00564 & $<$ & 0.01297 & $<$ & 0.04553 & & 0.01696 & 0.00428 & 0.00250 & 0.00077 & $<$ & 0.00053 & 0.01049 \\
\hline $\mathrm{Pu}-5$ & $<$ & 0.00526 & $<$ & 0.01331 & $<$ & 0.04532 & & 0.01608 & 0.00454 & 0.00244 & 0.00098 & $<$ & 0.00027 & 0.01050 \\
\hline $\mathrm{Pu}-6$ & $<$ & 0.00848 & $<$ & 0.01366 & $<$ & 0.04529 & & 0.01648 & 0.00539 & 0.00289 & 0.00099 & $<$ & 0.00068 & 0.01083 \\
\hline Avg. & $<$ & 0.0065 & $<$ & 0.0133 & $<$ & 0.0454 & & 0.0165 & 0.0047 & 0.0026 & 0.0009 & $<$ & 0.0005 & 0.0106 \\
\hline St.dev. & & 0.0018 & & 0.0003 & & 0.0001 & & 0.0004 & 0.0006 & 0.0002 & 0.0001 & & 0.0002 & 0.0002 \\
\hline \multirow[t]{2}{*}{ \%RSD } & & 27.2 & & 2.6 & & 0.3 & & 2.7 & 12.2 & 9.3 & 13.8 & & 41.3 & 1.8 \\
\hline & & & & $\mathrm{B}$ & & $\mathrm{Si}$ & & $\mathrm{Li}$ & $\mathrm{Na}$ & & & & & \\
\hline EA-1 & & & & 8.949 & & 2.030 & & 4.741 & 6.701 & & & & & \\
\hline EA-2 & & & & 9.106 & & 2.055 & & 4.814 & 6.990 & & & & & \\
\hline EA-2 & & & & 9.380 & & 2.111 & & 5.021 & 7.218 & & & & & \\
\hline EA Avg. & & & & 9.145 & & 2.065 & & 4.859 & 6.970 & & & & & \\
\hline St.dev. & & & & 0.218 & & 0.042 & & 0.146 & 0.259 & & & & & \\
\hline$\%$ RSD & & & & 2.385 & & 2.018 & & 2.996 & 3.720 & & & & & \\
\hline \multicolumn{15}{|l|}{ Reference } \\
\hline EA Avg. & & & & 8.348 & & 1.961 & & 4.783 & 6.673 & & & & & \\
\hline St.dev. & & & & 0.611 & & 0.188 & & 0.3675 & 0.451 & & & & & \\
\hline$\%$ RSD & & & & 7.320 & & 9.587 & & 7.684 & 6.759 & & & & & \\
\hline
\end{tabular}




\subsection{Results of the PCT-A on Heat-Treated Pu Frit X Glass}

Table 3-6 shows a summary of the various PCT's performed on the heat-treated Pu Frit X LaBS glass. The first three tests are PCT-A conditions using the can-in-canister thermal profile heat-treated glasses. The blank tests performed with ASTM-1 water are also included for comparison. The second three tests are PCT-A conditions using the isothermal $1250^{\circ} \mathrm{C}$ heat-treated glass. Details for the EA and ARM-1 glass are also shown. All tests were performed remotely in the SCF of SRNL. The PCTs performed in steel vessels used a wrench and holder system to tighten the vessels. The total mass loss during the 7 -day test was well below the allowable $5 \%$ of total starting leachant mass.

Concentration and $\mathrm{pH}$ data for the filtered leachates are shown in Table 3-7 in units of $\mathrm{mg} / \mathrm{L}$. Data shown with 'less than' values were below the instrument method detection limits times the appropriate dilution factor correction. There was no detectable Al or B values in the Pu Frit X glass leachates. Both blank solutions also had no detectable ICPES elements. No Hf was detected in any of the Pu Frit X glass leachates whereas ICPMS data for the blanks showed detectable elementals for $\mathrm{La}, \mathrm{Nd}$, Gd and $\mathrm{Hf}$, but not for $\mathrm{Pu}$.

The $\mathrm{pH}$ values for the heat-treated glass Pu Frit X leachates ranged from 6.6 to 6.9 and were in the same $\mathrm{pH}$ range as the starting neutral ASTM-1 water $\mathrm{pH} 6.6$ to 6.9 leachant values. The blank leachates were also neutral in the $\mathrm{pH}$ range of 6.7 to 7.5 . The EA leachate $\mathrm{pH}$ 's were in the range of 11.62 to 11.80 , which is in good agreement with published data in the range of 11.7 to 12.0 , or an average of 11.85 (Jantzen 1993). Comparison of the concentrations for the ARM-1 glass vs. control chart historical ranges (Jantzen 1995) shown at the bottom of Table 3-7 indicates that all measured values are within the control range. Comparison of ICP-AES analyzed MES shown at the bottom of Table 3-7, submitted along with the leachates indicates that average MES analyses agree with target to within $\pm 5 \%$.

Concentration data for the acid strip solutions are shown in Table 3-8 in units of $\mathrm{mg} / \mathrm{L}$. Aluminum was the only element detected in all of the ICP-AES acid strip analyses and some $\mathrm{Al}$ was detected in the blank strip solutions. There are $\mu \mathrm{g} / \mathrm{L}(\mathrm{ppb})$ and sub-ppb levels of $\mathrm{La}, \mathrm{Nd}, \mathrm{Hf}, \mathrm{Gd}$ and $\mathrm{Pu}$ detected in the blanks for ICP-MS. The acid strip volumes are also shown in Table 3-8. All of the ICP-MS elements $\mathrm{La}, \mathrm{Nd}, \mathrm{Gd}, \mathrm{Hf}$ and $\mathrm{Pu}$ were detected in the heat-treated Pu Frit X glass acid strip solutions.

Table 3-9 shows the calculated normalized release values for the Pu Frit X heat-treated glasses and the normalized release for the EA glass. Values shown with a 'less than' sign indicate that the leachate and/or the strip solution was an upper bound, thus making the calculated normalized release value an upper bound. Several values for the Al, B, Si and $\mathrm{Sr}$ normalized release rates for the Pu Frit X are upper bounds. Only the Hf values are upper bounds for the ICP-MS data. 
Comparison of the normalized elemental release rates for the Pu Frit $\mathrm{X}$ glass can-incanister data vs. the $1250^{\circ} \mathrm{C}$ heat-treated glass indicates no significant differences in normalized release for $\mathrm{La}, \mathrm{Nd}$ and $\mathrm{Gd}$. The precision for these elements in these two data sets was poor. Similar comparison for $\mathrm{Pu}$ indicates that the can-in-canister normalized release $\left(0.003 \pm 0.0004 \mathrm{~g} / \mathrm{m}^{2}\right)$ is $\sim 3 \mathrm{X}$ lower than the $1250^{\circ} \mathrm{C}$ heat-treated $\mathrm{Pu}$ glass data $\left(0.010 \pm 0.001 \mathrm{~g} / \mathrm{m}^{2}\right)$. The normalized Pu release for the $1250^{\circ} \mathrm{C}$ heat-treated glass is similar to Pu normalized release for quenched glass $\left(0.013-0.011 \mathrm{~g} / \mathrm{m}^{2}\right)$ previously shown in Section 3.3. A similar result of lower normalized Pu release in devitrified vs. amorphous $\mathrm{Pu}$ LaBS glasses was cited in previous testing that compared normalized $\mathrm{Pu}$ release from amorphous and devitrified LaBS Frit A glasses (Marra, 2006a). One possible explanation for the lower normalized $\mathrm{Pu}$ release from the can-in-canister Pu Frit $\mathrm{X}$ glasses is that the relatively high variation in crystalline species observed for this glass (vs. the quenched or $1250^{\circ} \mathrm{C}$ isothermal heat-treated glass) lowers the $\mathrm{Pu}$ release.

Measured normalized release rates for the EA glass in this PCT are averaged and compared to literature values (Jantzen, 1993). The measured averages for B, Si, Li and $\mathrm{Na}$ are slightly lower than the literature averages. However, for $\mathrm{Si}, \mathrm{Li}$ and $\mathrm{Na}$, there is overlap between the measured average plus one standard deviation and the literature average minus one standard deviation. Comparison of the PCT-A data for Pu Frit X glass vs. the EA glass data shows that the average normalized release for the Pu Frit $\mathrm{X}$ glass is $>400$ times lower based on B and > 30 times lower based on Si. Thus the Pu Frit X glass meets the durability criterion stated in the WAPS for HLW glasses. 
WSRC-STI-2006-00318

Revision 0

Table 3-6. Summary of PCTs Performed on Heat-Treated Pu Frit X Glass

\begin{tabular}{|c|c|c|c|c|c|c|c|c|c|c|c|c|c|c|}
\hline PCT Method & Vessel ID & Sample ID & $\begin{array}{c}\text { Glass } \\
\text { Mass (g) }\end{array}$ & $\begin{array}{c}\text { Leachant Mass } \\
(\mathrm{g})\end{array}$ & $\begin{array}{l}\text { Ratio Leachant } \\
\text { to Glass }\end{array}$ & $\begin{array}{c}\text { Calculated } \\
\text { Surface Area } \\
\left(\mathrm{m}^{\wedge} 2\right)\end{array}$ & $\begin{array}{c}\mathrm{SA} / \mathrm{V} \\
\left(\mathrm{m}^{\wedge}-1\right)\end{array}$ & $\begin{array}{c}\text { PCT Duration } \\
\text { (Days) }\end{array}$ & $\begin{array}{c}\text { Total Mass } \\
\text { Loss }\end{array}$ & $\begin{array}{c}\text { Effective SA/V } \\
\left(\mathrm{m}^{\wedge}-1\right)\end{array}$ & $\begin{array}{l}\% \text { Leachate } \\
\text { Mass Loss }\end{array}$ & & \begin{tabular}{|} 
Avg. Leachate \\
Mass Loss per Day \\
(g/day)
\end{tabular} & $\begin{array}{l}\text { Final } \\
\text { Leachate } \\
\text { Mass (g) }\end{array}$ \\
\hline PCT-A & P377 & PuXCan-1 & 1.713 & 17.142 & 10.01 & $2.14 \mathrm{E}-02$ & 1247 & 7 & 0.002 & 1247 & 0.0 & $<$ & 0.001 & 17.14 \\
\hline PCT-A & $\mathrm{P} 500$ & PuXCan-3 & 1.6 & 15.991 & 9.99 & $2.00 \mathrm{E}-02$ & 1249 & 7 & 0.102 & 1257 & 0.6 & & 0.015 & 15.889 \\
\hline PCT-A & 341 & Blk-1 & 0 & 16.959 & NA & NA & NA & 7 & 0 & NA & 0.0 & & 0.000 & 16.959 \\
\hline PCT-A & P381 & Blk-2 & 0 & 17.035 & NA & NA & NA & 7 & 0.001 & NA & 0.0 & $<$ & 0.001 & 17.034 \\
\hline PCT-A & P363 & PuX-1250-4 & 1.688 & 16.569 & 9.82 & $2.11 \mathrm{E}-02$ & 1272 & 7 & 0.18 & 1285 & 1.1 & & 0.026 & 16.389 \\
\hline PCT-A & P393 & $\mathrm{PuX}-1250-5$ & 1.654 & 16.499 & 9.98 & $2.06 \mathrm{E}-02$ & 1251 & 7 & 0.008 & 1252 & 0.0 & & 0.001 & 16.491 \\
\hline PCT-A & P457 & PuX-1250-6 & 1.623 & 16.287 & 10.04 & 2.03E-02 & 1244 & 7 & 0.012 & 1245 & 0.1 & & 0.002 & 16.275 \\
\hline PCT-A & P305 & ARM-1 & 1.7 & 16.766 & 9.86 & $3.52 \mathrm{E}-02$ & 2098 & 7 & 0.006 & 2099 & 0.0 & & 0.001 & 16.76 \\
\hline PCT-A & 336 & ARM-3 & 1.701 & 16.87 & 9.92 & 3.52E-02 & 2086 & 7 & 0 & 2086 & 0.0 & & 0.000 & 16.87 \\
\hline PCT-A & P356 & EA-1 & 1.708 & 17.113 & 10.02 & $3.53 \mathrm{E}-02$ & 2065 & 7 & 0 & 2065 & 0.0 & & 0.000 & 17.113 \\
\hline PCT-A & 337 & EA-2 & 1.705 & 17.081 & 10.02 & $3.53 \mathrm{E}-02$ & 2065 & 7 & 0 & 2065 & 0.0 & & 0.000 & 17.081 \\
\hline PCT-A & P382 & EA-3 & 1.706 & 17.1 & 10.02 & $3.53 \mathrm{E}-02$ & 2064 & 7 & 0.004 & 2065 & 0.0 & $<$ & 0.001 & 17.096 \\
\hline
\end{tabular}


WSRC-STI-2006-00318

Revision 0

Table 3-7. Concentration and pH Data for the Filtered Leachates from Heat-Treated Pu Frit X Glasses

\begin{tabular}{|c|c|c|c|c|c|c|c|c|c|c|c|c|c|c|c|c|c|c|c|c|c|}
\hline $\begin{array}{c}\text { PCT } \\
\text { Method }\end{array}$ & $\begin{array}{c}\text { Vessel } \\
\text { ID }\end{array}$ & Sample ID & $\mathrm{pH}$ & & $\mathrm{Al}$ & & B & & $\mathrm{Si}$ & $\mathrm{Sr}$ & & $\mathrm{Li}$ & & $\mathrm{Na}$ & $\mathrm{La}$ & $\mathrm{Nd}$ & $\mathrm{Gd}$ & & $\mathrm{Hf}$ & & $\mathrm{Pu}$ \\
\hline & & & & & $(\mathrm{mg} / \mathrm{L})$ & & $(\mathrm{mg} / \mathrm{L})$ & & $(\mathrm{mg} / \mathrm{L})$ & $(\mathrm{mg} / \mathrm{L})$ & & $(\mathrm{mg} / \mathrm{L})$ & & $(\mathrm{mg} / \mathrm{L})$ & $(\mathrm{mg} / \mathrm{L})$ & $(\mathrm{mg} / \mathrm{L})$ & $(\mathrm{mg} / \mathrm{L})$ & & $(\mathrm{mg} / \mathrm{L})$ & & $(\mathrm{mg} / \mathrm{L})$ \\
\hline PCT-A & P377 & PuXCan-1 & 6.94 & $<$ & 0.081 & & 0.973 & $<$ & 2.710 & 0.606 & & NP & & NP & 0.011 & 0.008 & 0.003 & $<$ & 0.003 & & 0.214 \\
\hline PCT-A & P471 & PuXCan-2 & 6.88 & $<$ & 0.081 & & 1.013 & $<$ & 2.710 & 0.667 & & NP & & $\mathrm{NP}$ & 0.030 & 0.011 & 0.006 & $<$ & 0.003 & & 0.218 \\
\hline PCT-A & P500 & PuXCan-3 & 6.82 & $<$ & 0.081 & & 0.882 & $<$ & 2.710 & 0.512 & & NP & & NP & 0.035 & 0.011 & 0.007 & $<$ & 0.003 & & 0.198 \\
\hline PCT-A & 341 & Blk-1 & 6.74 & $<$ & 0.024 & $<$ & 0.103 & $<$ & 0.813 & NA & $<$ & 0.054 & $<$ & 0.206 & 0.009 & 0.012 & 0.006 & & 0.005 & $<$ & 0.003 \\
\hline PCT-A & P381 & Blk-2 & 7.52 & $<$ & 0.024 & $<$ & 0.103 & $<$ & 0.805 & NA & $<$ & 0.054 & $<$ & 0.206 & 0.012 & 0.011 & 0.008 & & 0.006 & $<$ & 0.003 \\
\hline PCT-A & P363 & PuX-1250-4 & 6.71 & $<$ & 0.081 & & 0.778 & $<$ & 2.710 & 0.434 & & NP & & NP & 0.041 & 0.014 & 0.014 & $<$ & 0.003 & & 0.698 \\
\hline PCT-A & P393 & PuX-1250-5 & 6.58 & $<$ & 0.081 & & 0.751 & $<$ & 2.710 & 0.401 & & NP & & NP & 0.039 & 0.014 & 0.012 & $<$ & 0.003 & & 0.683 \\
\hline PCT-A & P457 & PuX-1250-6 & 6.82 & $<$ & 0.081 & & 0.865 & $<$ & 2.710 & 0.471 & & NP & & NP & 0.091 & 0.041 & 0.032 & $<$ & 0.003 & & 0.682 \\
\hline PCT-A & P305 & ARM-1 & 10.05 & & 4.97 & & 16.57 & & 62.83 & NP & & 14.25 & & 38.98 & NA & NA & NA & & NA & & NA \\
\hline PCT-A & 331 & ARM-2 & 9.96 & & 4.60 & & 17.47 & & 63.85 & NP & & 14.75 & & 39.99 & NA & NA & NA & & NA & & NA \\
\hline PCT-A & 336 & ARM-3 & 10.2 & & 4.87 & & 16.90 & & 63.18 & NP & & 14.52 & & 39.99 & NA & NA & NA & & NA & & NA \\
\hline PCT-A & P356 & EA-1 & 11.62 & & 0.98 & & 500.83 & & 825.90 & NP & & 170.69 & & 1547.00 & NA & NA & NA & & NA & & NA \\
\hline PCT-A & 337 & EA-2 & 11.8 & & 0.92 & & 504.92 & & 829.90 & NP & & 172.12 & & 1558.00 & NA & NA & NA & & NA & & NA \\
\hline PCT-A & P382 & EA-3 & 11.78 & & 0.88 & & 531.34 & & 862.40 & NP & & 181.88 & & 1639.00 & NA & NA & NA & & NA & & NA \\
\hline $\begin{array}{l}\text { ARM } \\
\text { Control } \\
\end{array}$ & & & & & & & $(13-23)$ & & $(49-73)$ & & & $(11-16)$ & & $(29-44)$ & & & & & & & \\
\hline $\begin{array}{l}\text { Average } \\
\text { MES } \\
\text { Measured }\end{array}$ & & & & & 3.88 & & 18.99 & & 50.99 & - & & 10.03 & & 85.24 & - & - & - & & - & & - \\
\hline $\begin{array}{l}\text { MES } \\
\text { Standard }\end{array}$ & & & & & 4.00 & & 20.00 & & 50.00 & - & & 10.00 & & 81.00 & - & - & - & & - & & - \\
\hline $\begin{array}{l}\text { Agreement } \\
\text { with } \\
\text { Standard }\end{array}$ & & & & & 0.97 & & 0.95 & & 1.02 & - & & 1.00 & & 1.05 & - & - & - & & - & & - \\
\hline
\end{tabular}

Notes:

$\mathrm{NP}=$ not present

$\mathrm{NA}=$ not analyzed 
WSRC-STI-2006-00318

Revision 0

Table 3-8. Concentration Data for the Acid Strip Solutions from Heat-Treated Pu Frit X Glasses

\begin{tabular}{|c|c|c|c|c|c|c|c|c|c|c|c|c|c|c|c|}
\hline PCT Method & $\begin{array}{c}\text { Vessel } \\
\text { ID }\end{array}$ & Sample ID & $\begin{array}{c}\text { Strip } \\
\text { Volume }\end{array}$ & $\mathrm{Al}$ & & B & & $\mathrm{Si}$ & & $\mathrm{Sr}$ & $\mathrm{La}$ & $\mathrm{Nd}$ & $\mathrm{Gd}$ & $\mathrm{Hf}$ & $\mathrm{Pu}$ \\
\hline & & & $(\mathrm{mL})$ & $(\mathrm{mg} / \mathrm{L})$ & & $(\mathrm{mg} / \mathrm{L})$ & & $(\mathrm{mg} / \mathrm{L})$ & & $(\mathrm{mg} / \mathrm{L})$ & $(\mathrm{mg} / \mathrm{L})$ & $(\mathrm{mg} / \mathrm{L})$ & $(\mathrm{mg} / \mathrm{L})$ & $(\mathrm{mg} / \mathrm{L})$ & $(\mathrm{mg} / \mathrm{L})$ \\
\hline PCT-A & P377 & PuXCan-1 & 18.238 & 1.320 & $<$ & 0.185 & $<$ & 1.460 & $<$ & 0.085 & 1.982 & 1.179 & 1.063 & 0.197 & 0.116 \\
\hline Blnk. Corr. & & & & 1.227 & & & & & & & 1.978 & 1.175 & 1.063 & 0.194 & 0.115 \\
\hline PCT-A & P471 & PuXCan-2 & 18.275 & 1.060 & $<$ & 0.185 & $<$ & 1.460 & $<$ & 0.085 & 0.332 & 0.275 & 0.324 & 0.030 & 0.052 \\
\hline Blnk. Corr. & & & & 0.967 & & & & & & & 0.328 & 0.272 & 0.324 & 0.028 & 0.051 \\
\hline PCT-A & P500 & PuXCan-3 & 18.265 & 1.270 & & 0.234 & $<$ & 1.460 & & 0.100 & 2.190 & 1.304 & 1.206 & 0.238 & 0.148 \\
\hline Blnk. Corr. & & & & 1.177 & & & & & & & 2.186 & 1.300 & 1.206 & 0.236 & 0.147 \\
\hline PCT-A & 341 & Blk-1 & 18.362 & 0.113 & $<$ & 0.185 & $<$ & 1.460 & $<$ & 0.085 & 0.004 & 0.004 & 0.004 & 0.003 & 0.001 \\
\hline PCT-A & P381 & Blk-2 & 18.291 & 0.074 & $<$ & 0.185 & $<$ & 1.460 & $<$ & 0.085 & 0.003 & 0.003 & 0.004 & 0.002 & 0.001 \\
\hline PCT-B & P363 & $\mathrm{PuX}-1250-4$ & 18.276 & 1.040 & $<$ & 0.185 & $<$ & 1.460 & $<$ & 0.085 & 1.548 & 1.035 & 1.014 & 0.307 & 0.309 \\
\hline Blnk. Corr. & & & & 0.931 & & & & & & & 1.544 & 1.031 & 1.014 & 0.304 & 0.308 \\
\hline PCT-B & P393 & $\mathrm{PuX}-1250-5$ & 18.252 & 1.370 & & 0.325 & $<$ & 1.460 & & 0.160 & 2.966 & 1.712 & 1.660 & 0.465 & 0.437 \\
\hline Blnk. Corr. & & & & 1.261 & & & & & & & 2.962 & 1.709 & 1.656 & 0.462 & 0.436 \\
\hline PCT-B & P457 & PuX-1250-6 & 18.274 & 1.040 & $<$ & 0.185 & $<$ & 1.460 & $<$ & 0.085 & 1.432 & 0.952 & 0.929 & 0.231 & 0.315 \\
\hline Blnk. Corr. & & & & 0.931 & & & & & & & 1.428 & 0.948 & 0.925 & 0.229 & 0.314 \\
\hline
\end{tabular}


WSRC-STI-2006-00318

Revision 0

Table 3-9. Normalized Release Values for Pu Frit X Quenched Glasses and EA Glass

\begin{tabular}{|c|c|c|c|c|c|c|c|c|c|c|c|c|c|c|}
\hline & & $\mathrm{Al}$ & & B & & $\mathrm{Si}$ & & $\mathrm{Sr}$ & $\mathrm{La}$ & $\mathrm{Nd}$ & $\mathrm{Gd}$ & & $\mathrm{Hf}$ & $\mathrm{Pu}$ \\
\hline & & $\mathrm{g} / \mathrm{m}^{\wedge} 2$ & & $\mathrm{~g} / \mathrm{m}^{\wedge} 2$ & & $\mathrm{~g} / \mathrm{m}^{\wedge} 2$ & & $\mathrm{~g} / \mathrm{m}^{\wedge} 2$ & $\mathrm{~g} / \mathrm{m}^{\wedge} 2$ & $\mathrm{~g} / \mathrm{m}^{\wedge} 2$ & $\mathrm{~g} / \mathrm{m}^{\wedge} 2$ & & $\mathrm{~g} / \mathrm{m}^{\wedge} 2$ & $\mathrm{~g} / \mathrm{m}^{\wedge} 2$ \\
\hline PuXCan-1 & $<$ & 0.02257 & $<$ & 0.02469 & $<$ & 0.04001 & $<$ & 0.03296 & 0.01198 & 0.00891 & 0.00873 & $<$ & 0.00323 & 0.00321 \\
\hline PuXCan-2 & $<$ & 0.02451 & $<$ & 0.02571 & $<$ & 0.04070 & $<$ & 0.03598 & 0.00225 & 0.00223 & 0.00283 & $<$ & 0.00053 & 0.00262 \\
\hline PuXCan-3 & $<$ & 0.03002 & & 0.02411 & $<$ & 0.04087 & & 0.02943 & 0.01432 & 0.01058 & 0.01065 & $<$ & 0.00418 & 0.00348 \\
\hline Avg. & $<$ & 0.0257 & $<$ & 0.0248 & $<$ & 0.0405 & $<$ & 0.0328 & 0.0095 & 0.0072 & 0.0074 & $<$ & 0.0026 & 0.0031 \\
\hline St.dev. & & 0.0039 & & 0.0008 & & 0.0005 & & 0.0033 & 0.0064 & 0.0044 & 0.0041 & & 0.0019 & 0.0004 \\
\hline$\%$ RSD & & 15.0 & & 3.3 & & 1.1 & & 10.0 & 67.3 & 61.1 & 55.0 & & 71.6 & 14.2 \\
\hline PuX-1250-4 & $<$ & 0.02292 & $<$ & 0.02015 & $<$ & 0.03950 & $<$ & 0.02430 & 0.00969 & 0.00800 & 0.00010 & $<$ & 0.00511 & 0.00965 \\
\hline PuX-1250-5 & $<$ & 0.03105 & $<$ & 0.02335 & $<$ & 0.04045 & & 0.02724 & 0.01872 & 0.01344 & 0.00010 & $<$ & 0.00788 & 0.01109 \\
\hline PuX-1250-6 & $<$ & 0.02382 & $<$ & 0.02269 & $<$ & 0.04090 & $<$ & 0.02688 & 0.00962 & 0.00784 & 0.00025 & $<$ & 0.00400 & 0.00989 \\
\hline Avg. & $<$ & 0.0259 & $<$ & 0.0221 & $<$ & 0.0403 & $<$ & 0.0261 & 0.0127 & 0.0098 & 0.0001 & $<$ & 0.0057 & 0.0102 \\
\hline St.dev. & & 0.0045 & & 0.0017 & & 0.0007 & & 0.0016 & 0.0052 & 0.0032 & 0.0001 & & 0.0020 & 0.0008 \\
\hline \multirow[t]{2}{*}{ \%RSD } & & 17.2 & & 7.7 & & 1.8 & & 6.1 & 41.3 & 32.7 & 57.9 & & 35.3 & 7.5 \\
\hline & & & & B & & $\mathrm{Si}$ & & $\mathrm{Li}$ & $\mathrm{Na}$ & & & & & \\
\hline EA-1 & & & & 6.949 & & 1.756 & & 4.200 & 5.993 & & & & & \\
\hline EA-2 & & & & 7.005 & & 1.764 & & 4.235 & 6.035 & & & & & \\
\hline EA-3 & & & & 7.374 & & 1.834 & & 4.476 & 6.351 & & & & & \\
\hline EA Avg. & & & & 7.110 & & 1.784 & & 4.304 & 6.126 & & & & & \\
\hline St.dev. & & & & 0.231 & & 0.043 & & 0.150 & 0.195 & & & & & \\
\hline$\%$ RSD & & & & 3.245 & & 2.398 & & 3.495 & 3.190 & & & & & \\
\hline \multicolumn{15}{|l|}{ Reference } \\
\hline EA Avg. & & & & 8.348 & & 1.961 & & 4.783 & 6.673 & & & & & \\
\hline St.dev. & & & & 0.611 & & 0.188 & & 0.368 & 0.451 & & & & & \\
\hline$\%$ RSD & & & & 7.320 & & 9.587 & & 7.684 & 6.759 & & & & & \\
\hline
\end{tabular}




\subsection{Comparison of Filtration vs. Ultrafiltration Data}

Table 3-10 compares the average leachate $\mu \mathrm{g} / \mathrm{L}$ concentrations for the filtered vs. the ultrafiltered leachates from all of the Pu Frit X PCT's. Ultrafiltered leachates were only submitted for ICP-MS. The ultrafiltered leachates used a dilution of $0.5 \mathrm{~mL}$ ultrafiltered leachate to $10.1 \mathrm{~mL}$ total volume. Data shown in Table 3-10 has been dilution corrected from the instrumental reported values. Average $\mu \mathrm{g} / \mathrm{L}$ data from Table 3-10 are plotted in Figure 3-8 through Figure 3-11. No Hf data was plotted since no detectable Hf was present in the leachates. The error bars shown on the figures are \pm 2 standard deviations to represent a $95 \%$ confidence interval. The filtered and ultrafiltered leachate concentrations for the quenched glasses trended in the order of $\mathrm{Pu}>\mathrm{La}>\mathrm{Nd} \sim \mathrm{Gd}$ with no detectable Hf. The filtered and ultrafiltered leachate concentrations for the heat-treated glasses were all lower than the corresponding quenched glasses and trended in the order of $\mathrm{Pu} \gg \mathrm{La} \sim \mathrm{Nd} \sim \mathrm{Gd}$ with no detectable Hf. Filtered and ultrafiltered $\mathrm{Pu}, \mathrm{La}, \mathrm{Nd}$ and $\mathrm{Gd}$ concentration data for the quenched Pu Frit X glasses are shown not to be statistically significantly different as the averages \pm 2 standard deviations show considerable overlap in Figure 3-8 through Figure 3-11. Similar comparisons for the two heat-treated glasses $(\mathrm{Pu}, \mathrm{La}, \mathrm{Nd}$ and $\mathrm{Gd}$ ) indicate a possible difference only in the average Pu values. For both the can-in-canister and the $1250^{\circ} \mathrm{C}$ heat-treated glasses, the average ultrafiltered $\mathrm{Pu}$ values are lower than the filtered $\mathrm{Pu}$ values. These average $\mathrm{Pu}$ concentration differences are about $38 \%$ as calculated from [(filtered - ultrafiltered)/ filtered]. These data suggest that nanometer-sized plutonium species, e.g., potential $\mathrm{Pu}$ colloidal species, are being filtered out of the ultrafiltered leachates. Further studies involving longer term corrosion tests on these heat-treated glasses and possible post-filtration ultra filter analyses (XRD and SEM/EDS performed on the filter media) would need to be performed to further investigate presence of colloidal plutonium. 
WSRC-STI-2006-00318

Revision 0

Table 3-10. Concentrations from Ultrafiltered (UF) and Filtered (Filt.) Leachates

\begin{tabular}{|c|c|c|c|c|c|c|c|}
\hline & & & & & Avg. $(\mu \mathrm{g} / \mathrm{L})$ & St.Dev. $(\mu \mathrm{g} / \mathrm{L})$ & $\%$ RSD \\
\hline \multirow[t]{8}{*}{$\mathbf{P u}$} & PCT-A & $\mathrm{PuX}, 1-3$ & UF & & 926.45 & 50.40 & 5.4 \\
\hline & & $\mathrm{PuX}, 1-3$ & Filt & & 973.12 & 103.09 & 10.6 \\
\hline & PCT-B & $\mathrm{PuX}, 4-6$ & UF & & 1489.25 & 3.80 & 0.3 \\
\hline & & $\mathrm{PuX}, 4-6$ & Filt & & 1545.15 & 76.39 & 4.9 \\
\hline & PCT-A & PuXCan,1-3 & UF & & 132.65 & 6.75 & 5.1 \\
\hline & & PuXCan,1-3 & Filt & & 209.85 & 10.50 & 5.0 \\
\hline & PCT-A & $\mathrm{PuX1250,4-6}$ & UF & & 416.15 & 17.62 & 4.2 \\
\hline & & $\mathrm{PuX1250,4-6}$ & Filt & & 687.48 & 8.97 & 1.3 \\
\hline \multirow[t]{8}{*}{ La } & PCT-A & $\mathrm{PuX}, 1-3$ & UF & & 512.69 & 48.54 & 9.5 \\
\hline & & $\mathrm{PuX}, 1-3$ & Filt & & 686.24 & 61.42 & 9.0 \\
\hline & PCT-B & $\mathrm{PuX}, 4-6$ & UF & & 894.31 & 146.37 & 16.4 \\
\hline & & $\mathrm{PuX}, 4-6$ & Filt & & 1031.43 & 161.20 & 15.6 \\
\hline & PCT-A & PuXCan,1-3 & UF & & 4.90 & 2.16 & 44.2 \\
\hline & & PuXCan,1-3 & Filt & & 25.14 & 12.67 & 50.4 \\
\hline & PCT-A & $\mathrm{PuX} 1250,4-6$ & UF & & 72.06 & 78.74 & 109.3 \\
\hline & & PuX1250,4-6 & Filt & & 57.02 & 29.43 & 51.6 \\
\hline \multirow[t]{8}{*}{ Nd } & PCT-A & $\mathrm{PuX}, 1-3$ & UF & & 130.29 & 23.36 & 17.9 \\
\hline & & $\mathrm{PuX}, 1-3$ & Filt & & 213.98 & 68.08 & 31.8 \\
\hline & PCT-B & $\mathrm{PuX}, 4-6$ & $\mathrm{UF}$ & & 223.94 & 31.89 & 14.2 \\
\hline & & $\mathrm{PuX}, 4-6$ & Filt & & 307.82 & 68.18 & 22.2 \\
\hline & PCT-A & PuXCan,1-3 & UF & $<$ & 19.96 & 0.03 & 0.1 \\
\hline & & PuXCan,1-3 & Filt & & 10.06 & 1.73 & 17.2 \\
\hline & PCT-A & $\mathrm{PuX} 1250,4-6$ & $\mathrm{UF}$ & & 58.91 & 61.06 & 103.6 \\
\hline & & PuX1250,4-6 & Filt & & 23.06 & 15.21 & 66.0 \\
\hline \multirow[t]{8}{*}{ Gd } & PCT-A & $\mathrm{PuX}, 1-3$ & UF & & 89.66 & 10.93 & 12.2 \\
\hline & & $\mathrm{PuX}, 1-3$ & Filt & & 121.96 & 14.01 & 11.5 \\
\hline & PCT-B & $\mathrm{PuX}, 4-6$ & $\mathrm{UF}$ & & 155.78 & 21.14 & 13.6 \\
\hline & & PuX,4-6 & Filt & & 189.59 & 26.85 & 14.2 \\
\hline & PCT-A & PuXCan,1-3 & UF & $<$ & 10.05 & 0.01 & 0.1 \\
\hline & & PuXCan,1-3 & Filt & & 5.23 & 1.93 & 36.8 \\
\hline & PCT-A & $\mathrm{PuX} 1250,4-6$ & UF & & 46.65 & 53.38 & 114.4 \\
\hline & & PuX1250,4-6 & Filt & & 19.36 & 10.97 & 56.7 \\
\hline \multirow[t]{8}{*}{ Hf } & PCT-A & $\mathrm{PuX}, 1-3$ & UF & $<$ & 9.87 & 0.22 & 2.3 \\
\hline & & $\mathrm{PuX}, 1-3$ & Filt & $<$ & 2.17 & 0.00 & 0.0 \\
\hline & PCT-B & $\mathrm{PuX}, 4-6$ & UF & $<$ & 9.74 & 0.01 & 0.1 \\
\hline & & PuX,4-6 & Filt & $<$ & 2.17 & 0.00 & 0.0 \\
\hline & PCT-A & PuXCan,1-3 & UF & $<$ & 9.73 & 0.01 & 0.1 \\
\hline & & PuXCan,1-3 & Filt & $<$ & 3.36 & 0.00 & 0.0 \\
\hline & PCT-A & $\mathrm{PuX1250,4-6}$ & UF & $<$ & 28.49 & 32.50 & 114.0 \\
\hline & & $\mathrm{PuX} 1250,4-6$ & Filt & $<$ & 3.36 & 0.00 & 0.0 \\
\hline
\end{tabular}




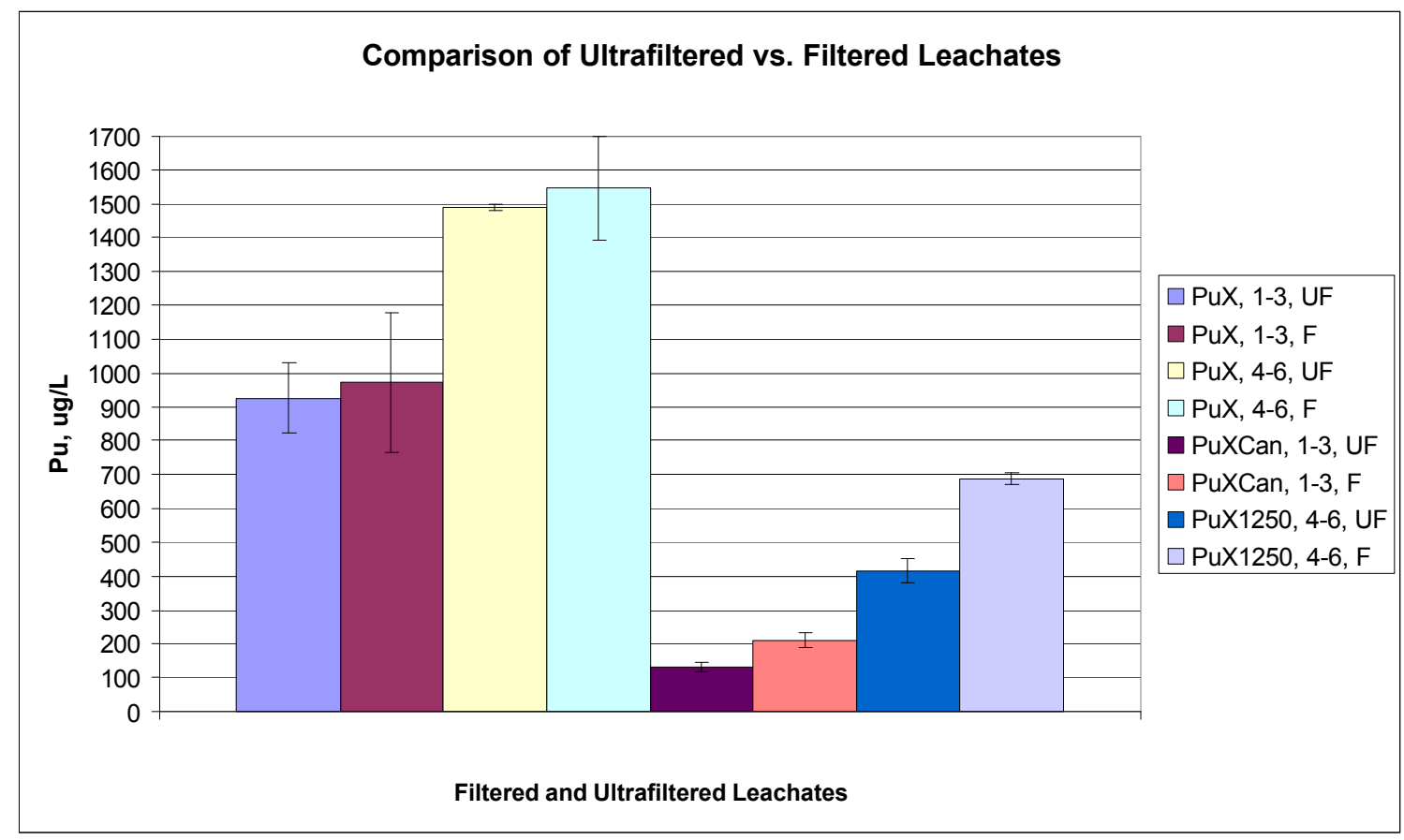

Figure 3-8. Pu Concentrations from Filtered and Ultrafiltered Leachates

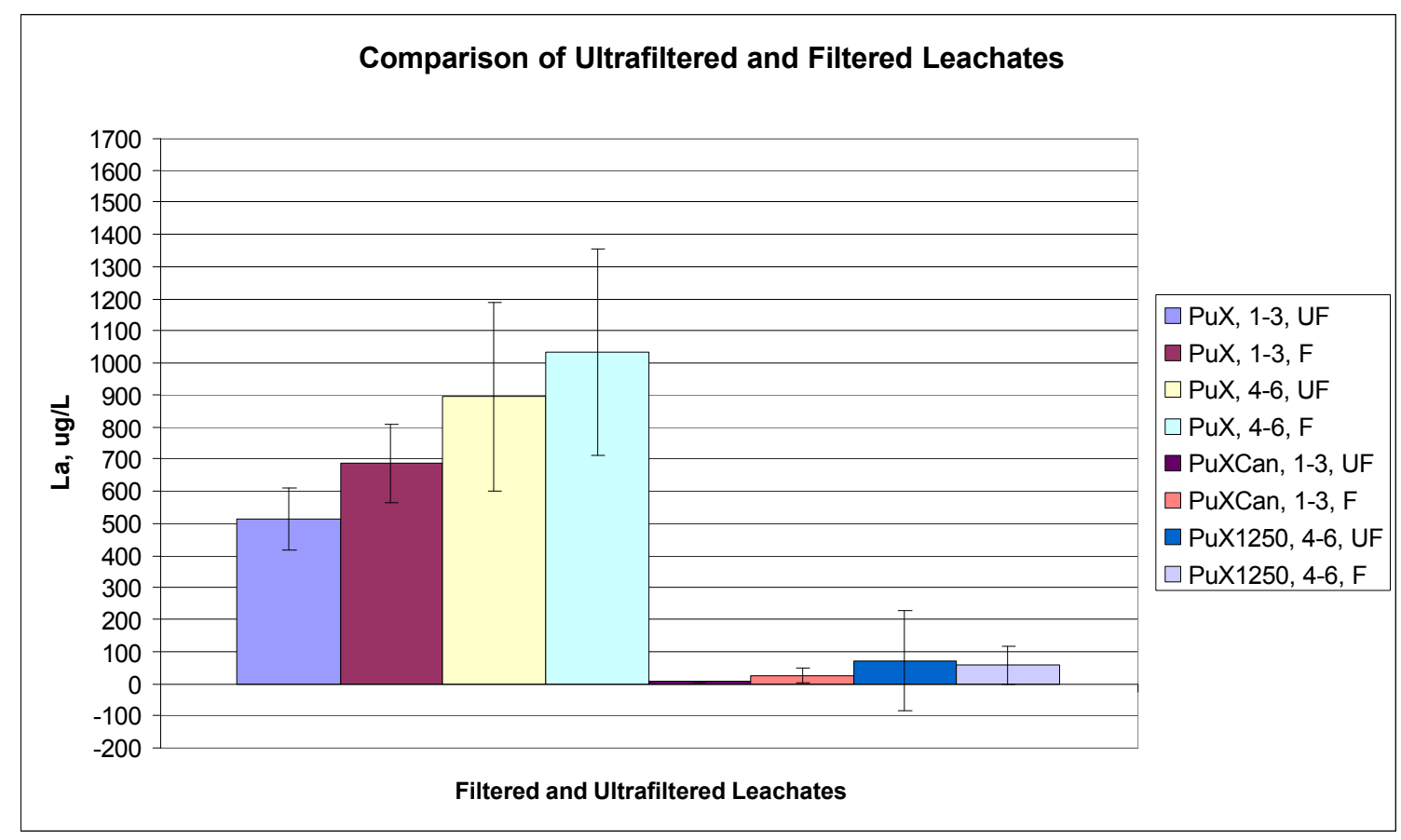

Figure 3-9. La Concentrations from Filtered and Ultrafiltered Leachates 


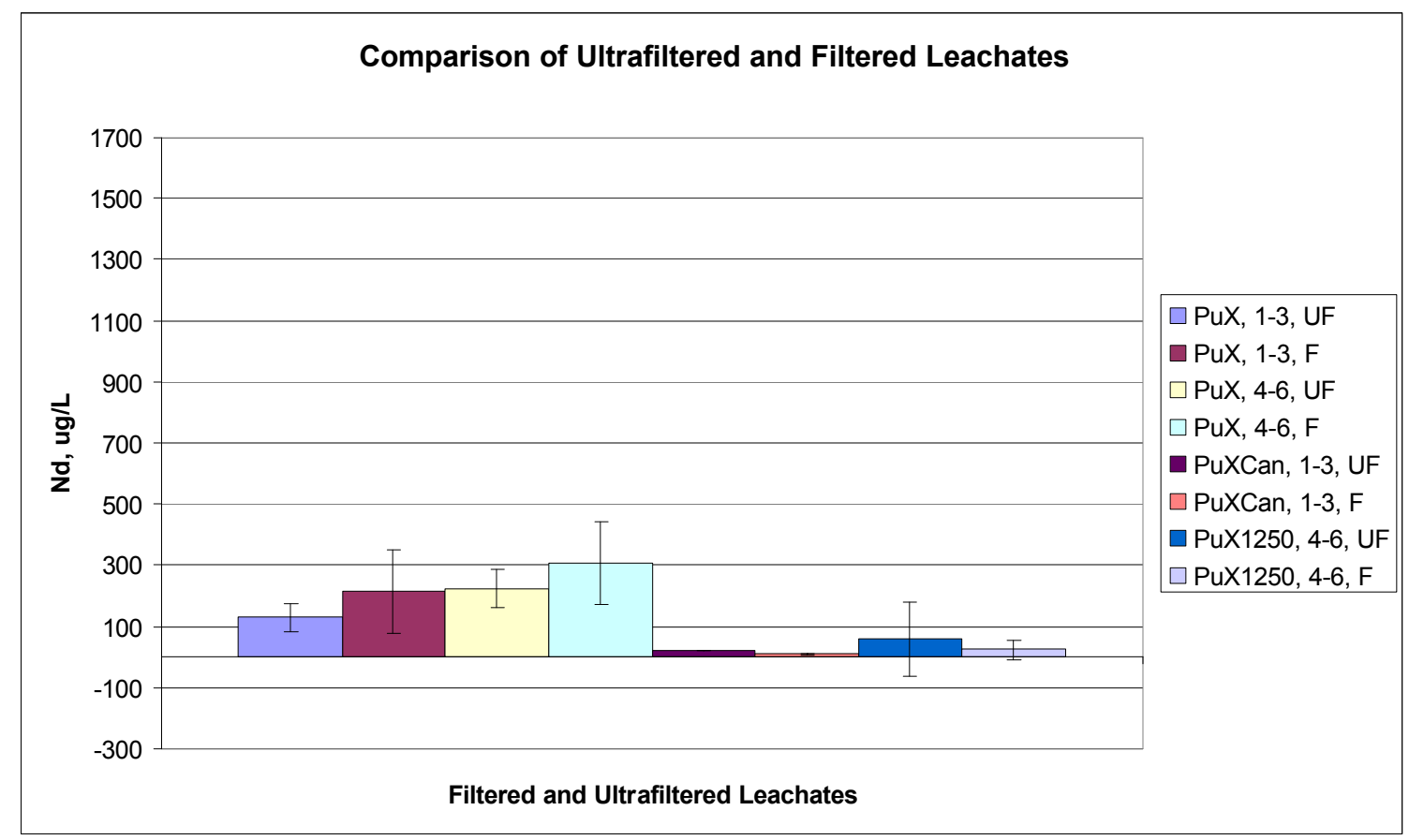

Figure 3-10. Nd Concentrations from Filtered and Ultrafiltered Leachates

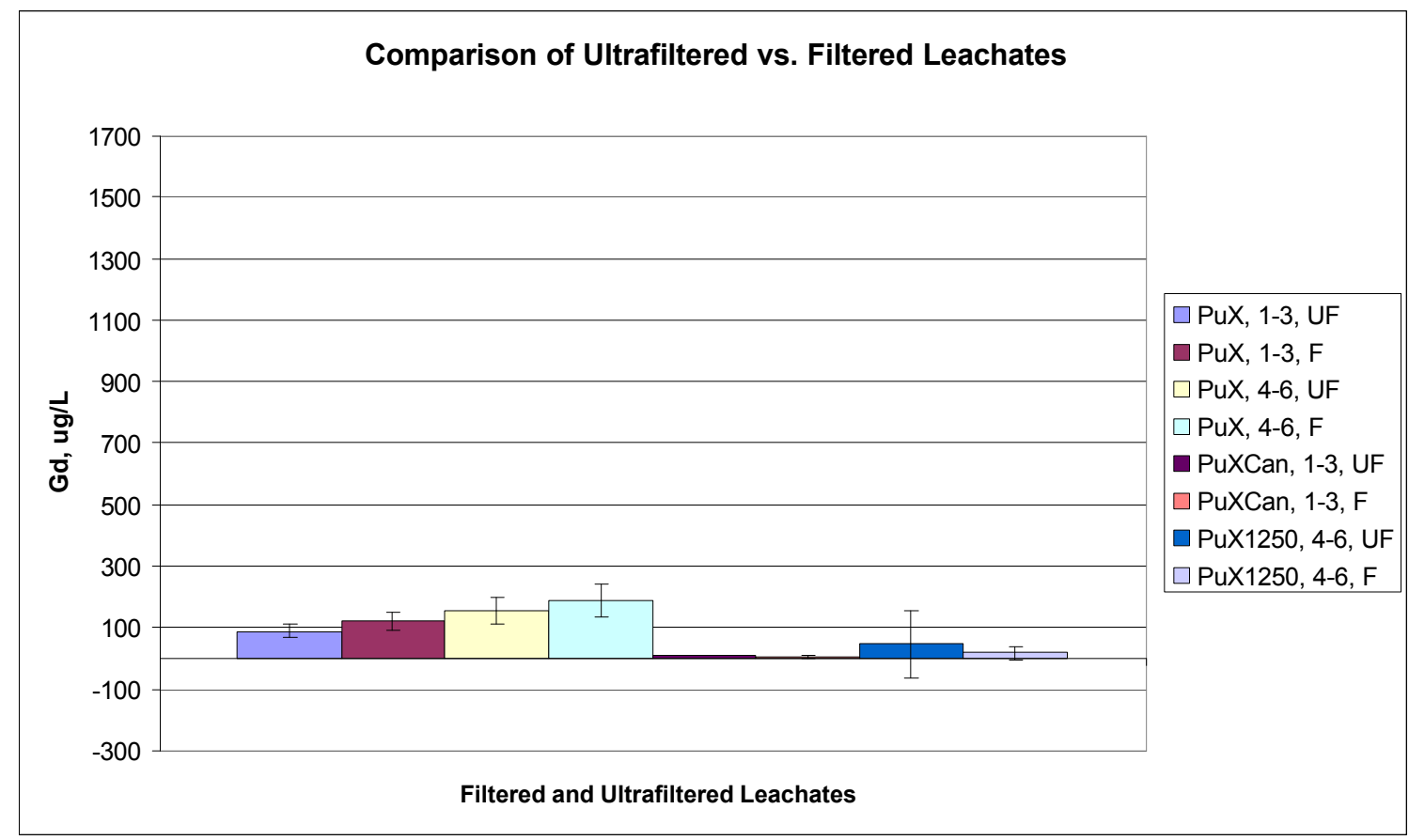

Figure 3-11. Gd Concentrations from Filtered and Ultrafiltered Leachates 


\subsection{CONCLUSIONS}

Plutonium containing LaBS Frit X composition glass was fabricated, analyzed and leach tested in this task. The following conclusions can be drawn from the testing:

- A small amount of undissolved $\mathrm{PuO}_{2}$ was present in the Pu Frit X glass after fabrication and quenching. The crystalline $\mathrm{PuO}_{2}$ was detectable by powdered sample XRD that has a previously shown nominal detection limit of crystalline $\mathrm{PuO}_{2}$ in amorphous glass of $\sim 0.2 \mathrm{wt} \%$ (Vienna, 1996). The undissolved particles had a disk-like morphology and likely formed via coarsening of particles in areas compositionally enriched in plutonium. Various heat treatments on the Pu Frit X glass resulted in crystalline phases consisting of $\mathrm{PuO}_{2}, \mathrm{Nd}_{2} \mathrm{Hf}_{2} \mathrm{O}_{7}$ and a potential $\mathrm{PuO}_{2}-\mathrm{HfO}_{2}$ solid solution. Many of these crystalline phases were located in cluster formations in the glass particles.

- $\quad$ PCT-A and PCT-B results on the Pu containing LaBS Frit X quenched glass showed that the glass was very durable and was greater than $30 \mathrm{X}$ to $400 \mathrm{X}$ more durable from silicon and boron release standpoint than the current Environmental Assessment (EA) glass used for repository acceptance.

- The normalized Pu elemental release values for the PCT-A tests on isothermal $1250^{\circ} \mathrm{C}$ heat-treated Pu Frit X glass were comparable with the PCT-A and PCT-B results for quenched $\mathrm{Pu}$ Frit $\mathrm{X}$ glass.

- Comparison of leached can-in-canister PCT-A results to the PCT-A and PCT-B quenched glass and the PCT-A isothermal $1250^{\circ} \mathrm{C}$ glass shows that the can-incanister normalized release for $\mathrm{Pu}$ is $\sim 3 \mathrm{X}$ lower. Observed lower normalized $\mathrm{Pu}$ elemental release from the can-in-canister Pu Frit X glass leachates could be related to the larger variation in Pu-related crystalline species identified in this glass vs. the other Pu Frit $\mathrm{X}$ glasses (quenched and $1250^{\circ} \mathrm{C}$ isothermal heattreated) used in this study.

- Ultrafiltration of the quenched Pu Frit X glass leachates did not show statistically significant differences in $\mathrm{La}, \mathrm{Nd}, \mathrm{Gd}$, $\mathrm{Hf}$ and $\mathrm{Pu}$ when compared to $0.45 \mu \mathrm{m}$ filtration. However, ultrafiltration of the isothermal $1250^{\circ} \mathrm{C}$ and can-in-canister $\mathrm{Pu}$ Frit $\mathrm{X}$ leachates indicates $\sim 30 \%$ less $\mathrm{Pu}$ is present vs. $0.45 \mu \mathrm{m}$ filtration. These data suggest presence of some colloidal $\mathrm{Pu}$ in the heat-treated glass leachates. 


\subsection{RECOMMENDATIONS / PATH FORWARD}

Several items were identified in this testing indicating where further analysis and testing are needed.

Microstructure characterization of the $\mathrm{Pu}$ Frit $\mathrm{X}$ glass shows evidence of a $\mathrm{PuO}_{2}-\mathrm{HfO}_{2}$ solid solution phase. However, quantitative determination of the relative amounts of $\mathrm{Pu}$ and $\mathrm{Hf}$ in this phase is not possible unless standard solid solution $\mathrm{PuO}_{2}-\mathrm{HfO}_{2}$ phases can be made and characterized. $\mathrm{PuO}_{2}-\mathrm{HfO}_{2}$ samples should be produced and characterized to support this effort.

PCT-B testing should be conducted for longer (up to one year) durations on the Frit B composition and the present Frit X composition (both quenched and heat-treated) to provide additional insight into colloid and alteration phase formation. Archived samples of Pu Frit B and Pu Frit X glass have been made in the present study to support these long term tests. Long term static PCT's could be conducted in an oven located inside of a radiochemical hood to allow for better monitoring and vessel tightening by hand vs. previous PCT's performed remotely in the SCF.

Analytical methods for dissolution and characterization of the Pu LaBS glasses have been preliminarily examined in this work. Surrogate frit dissolutions have been performed and the resulting dissolved frit solutions have been analyzed by non-radioactive sample instrument analyses using ICP-AES capable of analyzing for all eight of the frit elemental components. These data were then compared to separate analyses using radioactive sample instrument analyses (ICP-AES for Al, B, Si and Sr, and ICP-MS for Gd, Hf, La and $\mathrm{Nd}$ ) that would be used for analyses of actual Pu-bearing glasses. Initial results from this comparison indicate sufficient agreement between the methods (ICP-AES non-rad vs. combined ICP-AES and ICP-MS for radioactive solutions). Thus these preliminary glass characterization analyses should be extended to actual $\mathrm{Pu}$-bearing glasses to confirm the glass composition. 


\section{ACKNOWLEDGEMENTS}

The authors wish to acknowledge many colleagues who contributed to the completion of this effort. Irene Reamer and Phyllis Workman prepared the frit needed to prepare the plutonium glass. Dave Best and Pat Toole performed the Frit X chemical analyses using ICP-AES in the SRNL Process Science Analytical Laboratory (PSAL). John Scoggin provided the $\mathrm{PuO}_{2}$ to make the plutonium glass and directed the preparation and limited characterization of the $\mathrm{PuO}_{2}$ material. Phyllis Burkhalter prepared the plutonium glasses in the SCF. Sherry Vissage, Debbie Marsh, David Healy performed the leachate filtrations and prepared the leachate solutions for analyses. Several different Analytical Development personnel contributed. Mike Summer and Jack Durden performed the SEM analyses and Art Jurgensen and David Missimer performed the XRD analyses. June Hart was responsible for the radioactive solution ICP-AES analyses and Curtis Johnson directed the radioactive solution ICP-MS analyses.

The authors would also like to thank Bill Ebert of ANL and Denis Strachan of PNNL for technical advice and fruitful discussions regarding this work.

Finally, the authors would like to thank Mimi Jones for her support in the technical editing of this report. 


\section{REFERENCES}

Brown, G. E. Jr., (1995), F. Farges and G. Calas, "X-Ray Scattering and X-Ray Spectroscopy Studies of Silicate Melts," in 'Structure, Dynamics and Properties of Silicate Melts', J. F. Stebbins, P. F. McMillan and D. B. Dingwell (Eds.), Reviews in Mineralogy, V. 32, $317-410$.

BSC (2004), Defense HLW Glass Degradation, Bechtel SAIC Company, Report ANLEBS-MD-000016 Rev 02, Las Vegas, NV, (2004)

Carroll, D. G. (1963), “The System $\mathrm{PuO}_{2}-\mathrm{ZrO}_{2}$,” J. Am. Ceram. Soc., 46[4], 194-195 (1963).

Ebert, W. L., (2006), “Corrosion Testing of a Plutonium-Loaded Lanthanide Borosilicate Glass Made with Frit B”, ANL-06/35, Argonne National Laboratory, Argonne, IL, June 2006.

Jantzen, C. M. (1993), N. E. Bibler, D. C. Beam, C. L. Crawford and M. A. Pickett, "Characterization of the Defense Waste Processing Facility (DWPF) Environmental Assessment (EA) Glass Standard Reference Material (U), ' WSRC-TR-92-346, Rev. 1, 1993.

Jantzen, C. M. (1995), M. A. Pickett, K. G. Brown, T. B. Edwards, and D. C. Beam, "Process/Product Models for the DWPF: Part 1. Predicting the glass Durability from Composition Using a Thermodynamic Energy Hydration Model (THERMO) (U)," Volume 2: Appendix G, Pages G9 - G11, WSRC-TR-93-672, Rev. 1, 1995.

Jones, T. (2006), J. Marra, D. Immel, and B. Meers, “Glass Macrocracking Determination in Prototypic Canisters Containing Lanthanide Borosilicate Glass," WSRC-TR-2006-00015, January 2006, Washington Savannah River Company, Aiken, $\mathrm{SC}$.

Marra, J. C. (2006a), C. L. Crawford, and N. E. Bibler, "Glass Fabrication and Product Consistency Testing of Lanthanide Borosilicate Frit B Composition for Plutonium Disposition," WSRC-TR-2006-00033, January 2006, Washington Savannah River Company, Aiken, SC.

Marra, J. C. (2006b), D. K. Peeler, and C. M. Jantzen, "Development of an Alternative Glass Formulation for the Vitrification of Excess Plutonium," WSRC-TR-2006-00031, January 2006, Washington Savannah River Company, Aiken, SC.

Mellinger, G. B. (1983) and J. L. Daniel, "Approved Reference and Testing Materials for Use in Nuclear Waste Management Research and Development Programs," PNL-4955-1, Pacific Northwest Laboratory, December, 1983. 
Myers, R. B. (1998), G. A. Armantrout, C. M. Jantzen, A. Jostons, J. M. McKibben, H. F. Shaw, D. M. Strachan and J. D. Vienna, "Technical Evaluation Panel Summary Report: Ceramic and Glass Immobilization Options," UCRL-ID-129315, Plutonium Immobilization Project, Lawrence Livermore National Laboratory, January, 1998.

PCT, 2002, "Standard Test Methods for Determining Chemical Durability of Nuclear, Hazardous, and Mixed Waste Glasses and Multiphase Glass Ceramics: The Product Consistency Test (PCT)," American Society for Testing and Materials (ASTM), ASTM C1285-02, West Conshohoken, PA. 2002.

Pierce, E. M. (2006), and D. M. Strachan, "Progress Report on Single-Pass FlowThrough and Pressurized Unsaturated Flow Testing of $\mathrm{Hf}$ and Pu-bearing Lanthanide Borosilicate (LaBS) Glasses, Pacific Northwest National Laboratory, Richland, WA, September 2006.

Smith, M. E. (2000), G. L. Hovis, and E. L. Hamilton, "Phase 2 Can-in-Canister Cold Pour Tests for the Plutonium Immobilization Project," WSRC-TR-2000-00408, Washington Savannah River Company, Aiken, SC.

Speer, J. A. (1982), "Crystal Structure of Synthetic Hafnon, $\mathrm{HfSiO}_{4}$, Comparison with Zircon and the Actinide Orthosilicates", American Mineralogist, Vol. 67, 804-808 (1982)

Vienna, J. D. (1996), D. L. Alexander, H. Li, M. J. Schweiger, D. K. Peeler and T. F. Meaker, "Plutonium Dioxide Dissolution in Glass," PNNL-11346, UC-510, Pacific Northwest National Laboratory, Richland, WA, 1996. 